\title{
Pałac ,jakoż nigdzie w Polsce nie masz”. Saskie inspiracje $w$ architekturze warszawskiej rezydencji marszałka wielkiego koronnego Józefa Wandalina Mniszcha
}

$\mathrm{J}$ edną z najważniejszych inwestycji budowlanych w Warszawie w drugiej dekadzie XVIII stulecia było powstanie rezydencji Józefa Wandalina Mniszcha (1670-1747) przy ulicy Senatorskiej. O jej znaczeniu decydowały nowatorskie rozwiązania architektoniczne, czynniki polityczne i lokalizacyjne: położenie przy drodze królewskiej od Woli oraz bliskość pałacu Saskiego (il. 1). Sprawowany przez właściciela urząd marszałka wielkiego koronnego warunkował konieczność stworzenia przestrzeni ceremonialnej, dostosowanej między innymi do podejmowania poselstw i goszczenia monarchy. Splendor potęgowała obecność paradnego, poprzedzonego dekoracyjnym ogrodzeniem dziedzińca, oficyn oraz ogrodu. Przepych cechował również wnętrza pałacu, w którym organizowano bale, a także okazjonalne uroczystości, jak np. celebracja oktawy koronacji Augusta III 24 stycznia 1736 r. $^{1}$

Geneza i znaczenie niezwykle nowatorskich form architektonicznych obiektu stają się w pełni czytelne po uwzględnieniu roli politycznej i horyzontów intelektualnych właściciela, a także dokonywanych w tym okresie przekształceń siedzib królewskich w Europie. Najważniejszym punktem odniesienia jest architektura Saksonii. Należy też wspomnieć, że przy budowie siedziby marszałka zatrudniani byli między innymi rzemieślnicy pracujący równocześnie przy rezydencjach Augusta $\mathrm{II}^{2}$.

\footnotetext{
${ }^{1}$ Alina ŻÓRAWSKA-WITKOWSKA, Muzyka na polskim dworze Augusta III, Lublin 2012, s. 403.

${ }^{2}$ Sebastian Rybczyński informował listownie Mniszcha: Cieśle królewskiego dla obrabiania drzewa na dachy przyjatem; Wrocław, Biblioteka Zakładu Narodowego im. Ossolińskich (dalej: ZNiO), Archiwum Mniszchów, listy Sebastiana Rybczyńskiego z lat 1717-1718, sygn. 2664/I (dalej: 2664/I), k. 17; Spuściłem się na magistra, że więcej niż 18 mularzy miatem mieć, a on mnie zawiódt, mając królewska robotę i inne, to ich tam obraca, chociaż ode mnie prawie za nic codzień 16 tynfów z ordynansu Im Pan Generała bierze, teraz sam muszę się starać o mularzów przyczynienie (ibid., k. 21); magister cieśla Niemiec nie tylko swoich cieśli, których przyobiecał nie dodat mi na ten tydzień, ale jeszcze tych, których ja zaciagnatem zganiał mi, podją się pilnej roboty w żupie praskiej królewskiej, którq wiatr obalit (ibid., k. 37). ${ }^{3}$ Zob. Anna BERDECKA, Pałac Mniszchów przy ulicy Senatorskiej w Warszawie, Warszawa 1951, niepublikowana praca magisterska, promotor prof. Stanisław Lorentz, Uniwersytet Warszawski, Instytut Historii Sztuki. Założenie rezydencjonalne omawiali m.in. Aleksander KRAUSHAR, Resursa Kupiecka w Warszawie. Dawny Pałac Mniszchów (1820-1928), Warszawa 1928; Marek KWIATKOWSKI, Pałac Mniszchów w Warszawie - ambasada królestwa Belgii, Warszawa 2009. Założenie ogrodowe dokładniej przeanalizowała Jolanta PUTKOWSKA, „Ogród przy warszawskiej
} 


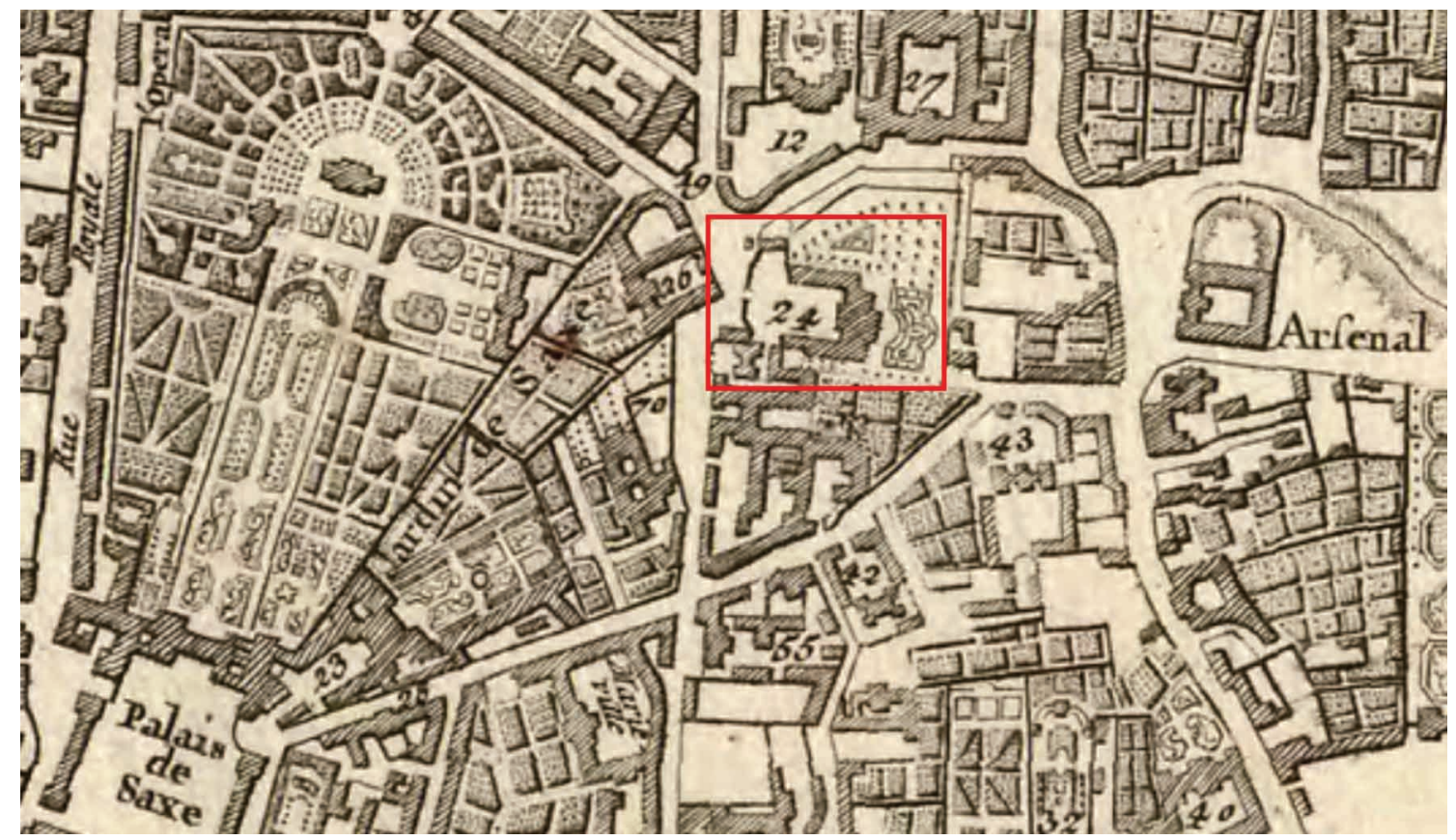

1. Pałac Mniszchów w Warszawie, fragment Plan de Varsovie Giovanniego Antonia Rizzi-Zannoniego, 1772. Fot. Ślaska Biblioteka Cyfrowa

Rezydencja Józefa Wandalina Mniszcha od lat budziła zainteresowanie badaczy analizujących historię obiektu i założenia ogrodowego ${ }^{3}$. Na omówienie oczekuje nadal duża ilość archiwaliów dokumentujących proces budowlany, a także dostarczających informacji o postaci głównego architekta - Burkharda Christopha von Münnicha ${ }^{4}$ Na wstępie warto raz jeszcze podkreślić, że autorem (bądź współautorem) projektu nie był Carlo Antonio Bay, jak uznano na podstawie niepoprawnie odczytanej daty w liście tegoż architekta ${ }^{5}$. Chociaż błąd ten stwierdzono już dawno, jednakże do dziś część badaczy faktu tego nie dostrzegła. Ostatnio jako swoje nowe odkrycie dawno znaną właściwą datę ogłosiła Monika Wyszomirska ${ }^{6}$. Nie jest też możliwe jednoznaczne potwierdzenie, że list z $1709 \mathrm{r}$.

rezydencji Józefa Wandalina Mniszcha, marszałka wielkiego koronnego, kasztelana krakowskiego”, [w:] „,Hortus vitae". Ksiega pamiatkowa dedykowana Andrzejowi Michałowskiemu, red. Marian ARSZYŃSKI, Andrzej MICHAŁOWSKI, Warszawa 2001, s. 191-195; ead., „Warszawski zespół rezydencjonalny Józefa Wandalina Mniszcha, marszałka wielkiego koronnego, kasztelana krakowskiego", Prace Naukowe Wydziału Architektury Politechniki Warszawskiej, 2002, t. 2, s. 105-118. Na temat dziejów pałacu zob. też: Alina BARCZYK, „Ambasada Królestwa Belgii w Warszawie. Forma architektoniczna i jej geneza", [w:] Pałac i willa. Ponowoczesne przygody idei i formy, red. Mariusz KĘPIŃSKI, Sebastian LATOCHA, Katarzyna SCHATT-BABIŃSKA, Łódź 2016, s. 95-107; Bożena POPIOŁEK, „Będzie to pałac osobliwej magnificencyi... Rzecz o warszawskim pałacu Józefa Wandalina Mniszcha, marszałka wielkiego koronnego", [w:] Staropolski oglad świata. Nulla dies sine linea. Ksiega jubileuszowa dedykowana profesorowi Bogdanowi Rokowi w 70. rocznicę urodzin, red. Elżbieta KOŚCIK, Filip WOLAŃSKI, Rościsław ŻERELIK, Toruń 2017, s. 205-218.

${ }^{4}$ ZNiO, Archiwum Mniszchów. Listy różnych osób z lat 1716-1791. Lit. M, sygn. 2697/II; (dalej: 2697/II), passim; ZNiO, 2664/I, passim; KWIATKOWSKI, op. cit., s. 13; POPIOŁEK, op. cit., s. 210-212.

${ }^{5}$ Data 1719 widnieje w szczegółowym wykazie listów z teki, w której znajduje się wzmiankowany list Baya; zob. ZNiO, Archiwum Mniszchów. Listy różnych osób z lat 1713-1775. Lit. A-Bia, sygn. 2688/II.

${ }^{6}$ Monika WYSZOMIRSKA, „Ruch budowlany w Warszawie w dobie Sejmu Niemego z perspektywy pisarza dekretowego kancelarii wielkiej koronnej Sebastiana Fabiana Rybczyńskiego”, [w:] Sejm niemy. Między mitem a reforma państwa, red. Michał ZWIERZYKOWSKI, Warszawa 2019, s. 333. Badaczka podała informację, że błąd powtarzany jest nie tylko w pracach sprzed kilku dekad, ale też w najnowszych opracowaniach, m.in. w moim artykule z roku 2016 (BARCZYK, op. cit.). W rzeczywistości Carlo Bay nie został w nim uwzględniony wśród architektów, którzy brali 


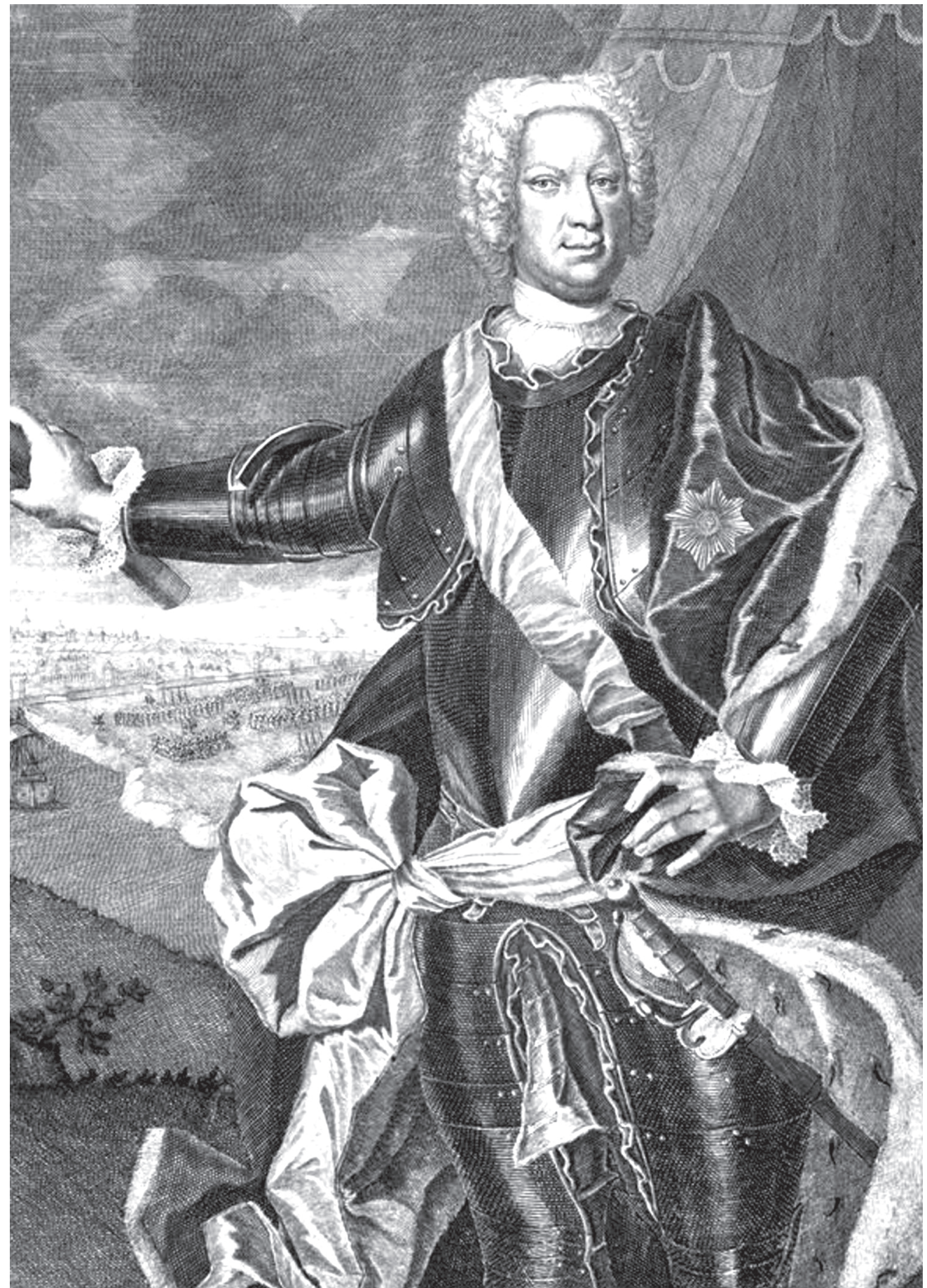

2. Christoph Burchardt Graf von Münnich, 1737.

Fot. Sächsische Landesbibliothek, Drezno

był kierowany do Józefa Wandalina Mniszcha, ani że dotyczyć miał jednej z „fabryk” z terenu Warszawy. W niniejszym artykule pragnę zarysować kilka wybranych aspektów,

udział w powstaniu pałacu Mniszchów przy ul. Senatorskiej, ponieważ właściwa data powstania listu, rok 1709, od lat nie budzi wątpliwości. Ponadto wskazanie przez Monikę Wyszomirską w przypisie zakresu stron całego artykułu, który próbuje zdeprecjonować, nie podając strony, na której rzekomo błędna informacja pojawia się sugeruje, że do jego treści nawet nie sięgnęła. 
obrazujących skomplikowany proces budowy i nowatorską formę architektoniczną pałacu Mniszcha na tle budownictwa czasów Wettynów ${ }^{7}$.

\section{Budowa rezydencji marszalkowskiej}

Posesja przy ulicy Senatorskiej (nr hip. 471) została własnością Józefa Wandalina Mniszcha najpóźniej w drugiej dekadzie XVIII w. ${ }^{8}$ Za moment zakupu przyjmowane są lata $1708-1709^{9}$ lub rok $1714^{10}$. Ostatnia $\mathrm{z}$ dat wydaje się bardziej prawdopodobna, mogłaby bowiem wiązać się z objęciem rok wcześniej funkcji marszałka wielkiego koronne-

\footnotetext{
${ }^{7}$ Rekonstrukcję procesu budowlanego i form dawnego pałacu Mniszchów dokumentują przede wszystkim zbiory korespondencji z lwowskiej Biblioteki Stefanyka, wrocławskiego Ossolineum, archiwów i bibliotek warszawskich (AGAD, $\mathrm{BN})$ oraz krakowskich (BCz, PAU i PAN). Szczególnie cenne informacje zawierają listy kierowane przez nadzorującego fabrykę Sebastiana Rybczyńskego oraz przez architekta Burkharda Christopha von Münnicha do Józefa Wandalina i Konstancji z Tarłów Mniszchów, a także pisma przesyłane przez samego marszałka do żony. Wygląd głównego korpusu, jak i całego założenia pałacowego w poszczególnych fazach udokumentowano na sztychach i obrazach, których najsłynniejszymi egzemplifikacjami są bordiura planu Ricaud de Tirregaille'a oraz weduta Canaletta. Podstawą dla weryfikacji ustaleń jest też istniejąca bryła pałacu. Wbrew powszechnie przyjętym informacjom w obiekcie czytelne pozostają elementy wskazujące na pierwotną formę, kształtowaną w XVII i XVIII w. Zniszczenia rezydencji po 1945 r. oszacowano na $85 \%$. W rzeczywistości uszkodzenia murów i fundamentów wynosiły zaledwie 30\%, a ogólny współczynnik degradacji wyprowadzono ze średniej uwzględniającej całkowitą destrukcję między innymi dachu i instalacji; zob. Stefan KRASIŃSKI, Resursa Kupiecka - Senatorska 40, Warszawa 1959, s. 1, maszynopis, Archiwum Stołecznego Konserwatora Zabytków. Jeszcze po połowie XX stulecia widoczne były XVIII-wieczne relikty, wspomniane w pracy Berdeckiej (op. cit., passim). Wyszczególnienie zakresu ingerencji jest możliwe dzięki dokumentacjom sporządzonym podczas badań archeologicznych, projektom odbudowy autorstwa Stanisława Brukalskiego oraz rysunkom prezentującym koncepcję adaptacji na siedzibę Ambasady Królestwa Belgii (zob. Stanisław BRUKALSKI, Odbudowa Pałacu Mniszchów. Projekt, Warszawa 1949, maszynopis, Archiwum Stołecznego Konserwatora Zabytków, passim) i pomiarom współczesnym (zob. Grażyna MADUROWICZ, Marek TYSZKA, Remont Ambasady Królestwa Belgii w Warszawie. Projekt budowlany - architektura, Warszawa 2001, maszynopis, Archiwum Stołecznego Konserwatora Zabytków, passim). Na weryfikację ustaleń pozwoliła analiza in situ piwnic oraz kondygnacji naziemnych, zmiany podziałów wnętrz pozostały bowiem czytelne m.in. w dodatkowych wzmocnieniach konstrukcji, wprowadzonych w miejscach pierwotnego występowania ścian.

${ }^{8}$ Teren ten w XV stuleciu należał do Baryczków, następnie stał się własnością kościoła pw. Świętego Krzyża. W 1556 r. działkę oddano w tymczasową dzierżawę Zembrzuskim, a w 1624 r. sprzedano Zygmuntowi Kazanowskiemu, podkomorzemu wielkiemu litewskiemu, który wybudował drewniany dwór. Majątek odziedziczyli następnie podkomorzy nadworny koronny, Adam Kazanowski. O budowli mieszkalnej wspomniał w Gościńcu albo krótkim opisaniu Warszawy Adam Jarzębski (1643): "Dwór [...] na Reformackiej ulicy” scharakteryzowano jako obiekt o znacznej skali, widoczny z oddali i poprzedzony wielkim dziedzińcem. Dwie drogi dojazdowe prowadziły od strony ulicy oraz wału. Pokoje miały być urządzone "piękną inwencyją"; zob. Adam JARZĘBSKI, Gościniec albo krótkie opisanie Warszawy, Warszawa 1909, s. 98. Po śmierci podkomorzego w 1649 r. dwór pozostał w rękach jego małżonki, Elżbiety ze Słuszków. W kolejnych dekadach następowała kilkukrotna zmiana właścicieli. Posesję kupowali kolejno: wojewoda lubelski Władysław Rey, wojewoda poznański Krzysztof Grzymułtowski. Między 1692 a 1701 r. teren został sprzedany przez spadkobierców wojewodzie kaliskiemu Feliksowi Aleksandrowi Lipskiemu, inicjatorowi budowy nowego dworu, niezależnego od istniejącej wcześniej drewnianej siedziby. Finalizację prac uniemożliwiła śmierć właściciela, a sam grunt stał się przedmiotem sporów między wdową, Urszulą z Krasickich, i księżmi misjonarzami. Duchowni podjęli wówczas jedną z kolejnych prób przejęcia posesji. Z polecenia zakonników w 1708 r. sporządzono inwentarz, dzięki któremu został udokumentowany stan zabudowy. W dokumencie potwierdzono istnienie zarówno dworu drewnianego, jak i murowanego mającego 20 par drzwi i 34 okna. Za siedzibą znajdował się regularny ogród z sadem. Po uzyskaniu zadośćuczynienia w wysokości 3000 tynfów księża misjonarze zrzekli się praw do ziemi. Urszula Lipska jako prawowita właścicielka podjęła decyzję o sprzedaży majątku; zob. BERDECKA, op. cit., passim; Eugeniusz SZWANKOWSKI, Ulice i place Warszawy, Warszawa 1970, s. 192; PUTKOWSKA, „Warszawski zespół rezydencjonalny...”, s. 107; KWIATKOWSKI, op. cit., s. 9; BARCZYK, op. cit., s. 95-96; POPIOŁEK, op. cit., s. 205-206.

${ }^{9}$ PUTKOWSKA, „Warszawski zespół rezydencjonalny...”, s. 106.

${ }^{10}$ BERDECKA, op. cit., s. 7.
} 
go $^{11}$, choć oczywiście finalizacje analogicznych transakcji niejednokrotnie bywały procesami kilkuletnimi ${ }^{12}$. Powyższą teorię dokumentuje źródłowo potwierdzony czas budowy pałacu - lata 1717-1718 ${ }^{13}$. W chwili zakupu na terenie posesji istniał murowany, nieukończony dwór o 34 oknach, przy którym prace przerwano z powodu śmierci inicjatora budowy, wojewody kaliskiego Feliksa Aleksandra Lipskiego w 1702 r. ${ }^{14} \mathrm{~W}$ czasach Mniszcha obiekt przekształcono w wielkoskalowe założenie rezydencjonalne. Analiza zachowanych archiwaliów pozwala na jednoznaczne powiązanie prac z generałem Burkhardem Christophem von Münnichem, który jako inżynier wodny i architekt militaris pełnił służbę u Augusta II (il. 2). Wcześniejszy udział w wyprawach wojskowych zaowocował znajomością architektury włoskiej i francuskiej ${ }^{15}$. Największy wpływ na jego projekty miało jednak środowisko saskie. Warto wspomnieć, że sam graf zasłynął jako budowniczy Twierdzy Pietropawłowskiej, gdzie kontynuował prace po śmierci Domenica Trezziniego w 1734 r. ${ }^{16}$ Wbrew powszechnie przyjętym ustaleniom Münnich wracał jeszcze do Warszawy w 1721 r., 26 kwietnia i 16 maja 1735 r. wydawał w stolicy kolacje - druga z nich została zorganizowana z okazji koronacji cesarzowej Anny Iwanowny ${ }^{17}$. Münnich nie był jednak od początku odpowiedzialny za tworzenie projektu budowy. W listach do marsza1ka wielkiego koronnego z 14 sierpnia i 17 listopada 1717 r. podkreślał, że wprowadzone rozwiązania (m.in. nowatorski mansardowy dach) pozwolą na zwiększenie wygody

\footnotetext{
${ }^{11}$ BARCZYK, op. cit., s. 96. Na temat zakresu kompetencji marszałka wielkiego koronnego oraz pozycji społecznej rodów, których przedstawiciele piastowali powyższe stanowisko zob. Krzysztof WIŚNIEWSKI, Urząd marszałkowski koronny w bezkrólewiach XVII-XVIII wieku (1632-1736), Warszawa 2015, passim.

${ }^{12}$ Analogiczną sytuację można wskazać m.in. w Dęblinie, gdzie Józef Wandalin Mniszech mieszkał przed oficjalnym przejęciem dóbr. Do „Marszałka W. Koronnego uprzejmie nam miłego w Dęblinie” skierowany był list królewski z listopada 1725 r., podczas gdy zakup rezydencji nastąił w roku kolejnym; zob. Aleksander KRÓL, „Dęblin”, Przeglad Lotniczy, 1937, nr 10, s. 1362; zob. też: Alina BARCZYK, „Akacyja biała z Łazienek [...], Thuja occidentalis z Królikarni. Założenie pałacowo-ogrodowe w Dęblinie w drugiej połowie XVIII stulecia” [w:] Ars et Scientia, t. 8, red. Alina BARCZYK, Błażej CIARKOWSKI, Krzysztof STEFAŃSKI, Łódź 2016, s. 20; ead., Pałac w Dęblinie. Inwentarze z czasów Michała Jerzego Wandalina Mniszcha, Kraków 2017, s. 9.

${ }^{13} \mathrm{ZNiO}, 2664 / \mathrm{I}$, passim; 2697/II, s. 169-174.

${ }^{14}$ BERDECKA, op. cit., s. 5; BARCZYK, „Ambasada...”, s. 96; POPIOŁEK, op. cit., s. 205.

${ }^{15}$ Burkhard Christoph von Münnich urodził się 9 V 1683 r. w Neuenhuntorf. Specjalizował się w inżynierii wodnej, służył w armii alzackiej, pełnił po 1701 r. rolę fortyfikatora we wschodniej Fryzji. Jako major korpusu pieszego uczestniczył w walkach we Włoszech, Niderlandach i Francji. Prace dla Józefa Wandalina Mniszcha i jego małżonki wykonywał będąc w służbie u Augusta II. Od 1717 r. był generalnym inspektorem sił polskich, jednak po konflikcie z Flemmingiem przeszedł pod zwierzchnictwo cara Piotra I. Przez dwie dekady, w latach 1742-1762, Münnich przebywał na zesłaniu na Syberii. Zmarł w roku 1767; zob. Walter HENTSCHEL, Die sächsische Baukunst des 18. Jahrhunderts in Polen, Berlin (Ost) 1967, s. 39-42. Korespondencja Münnicha zachowała się Landesarchiv Sachsen-Anhalt w Dessau: Korrespondenz Fürst August Ludwigs mit dem Grafen von Münnich zu Sankt Petersburg, 1749-1751, sygn. Z 70, A 10 Nr. 22; Schreiben des russischen Oberhofmeisters Burkhard Christoph Graf von Münnich (1683-1767) an die Fürstin Johanne Elisabeth von Anhalt-Zerbst (1712-1760) und Briefe der Großfürstin Katharina von Russland (1729-1796) an ihren Vater Christian August von Anhalt-Zerbst, sygn. Z 88, F 106 Nr. 24; i w Rosyjskim Państwowe Archiwum Akt Dawnych w Moskwie (Rossijskij Gosudarstwiennyj Archiw Driewnich Aktow): Разряд XI. Переписка разных лиц XVII-XIX вв. (коллекция) Государственного архива Российской империи. Личные документы и переписка: Ф. Лефорта, В. Монса, А. Д. Меньшикова, П. П. Шафирова, Б. П. Шереметева, Г. И. Головкина, А. И. Остермана, Б. Миниха, Э. Бирона, П. Ягужинского, А. П. Волынского, кн. кн. Кантемиров, МусиныхПушкиных, Бестужевых-Рюминых, Шуваловых, М. И. Воронцова, Н. И. Панина, Г. А. Потемкина, П. А. Зубова, министра финансов Д. Гурьева, А. С. Меншикова, А. К. Разумовского и др., fond 11, ор. 1.

${ }^{16}$ Józef POKLEWSKI, „Domenico Trezzini (ok. 1670-1734) - architekt Piotra I”, [w:] Artyści znad jezior lombardzkich w nowożytnej Europie. Prace dedykowane pamięci Profesora Mariusza Karpowicza, red. Mariusz SMOLIŃSKI, Renata SULEWSKA, Warszawa 2015, s. 218-219.

${ }^{17}$ ŻÓRAWSKA-WITKOWSKA, op. cit., s. 396-397.
} 


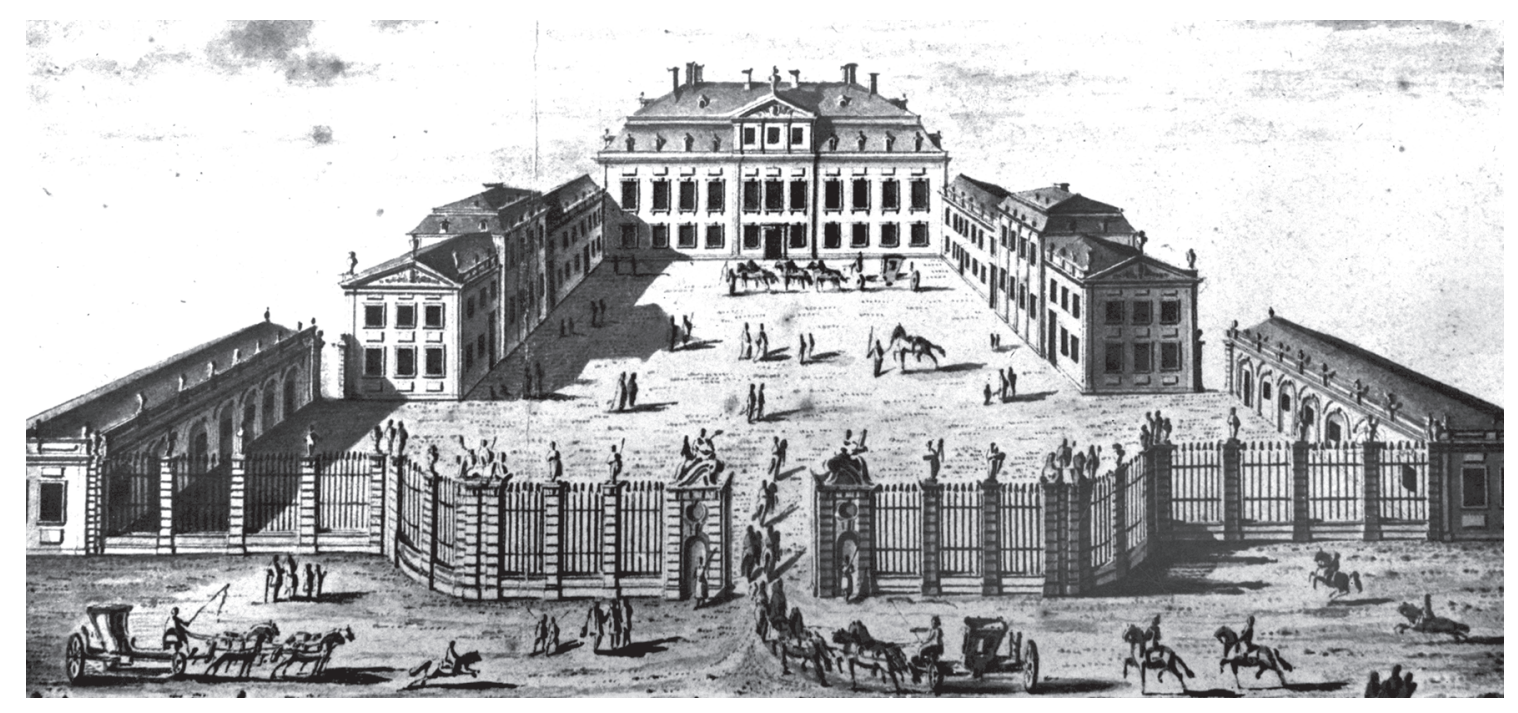

3. Pałac Mniszchów w Warszawie, fragment Prospect von Warschau Franza Conrada Schmidta, 1740. Fot. Sächsisches Hauptstaatsarchive, Drezno

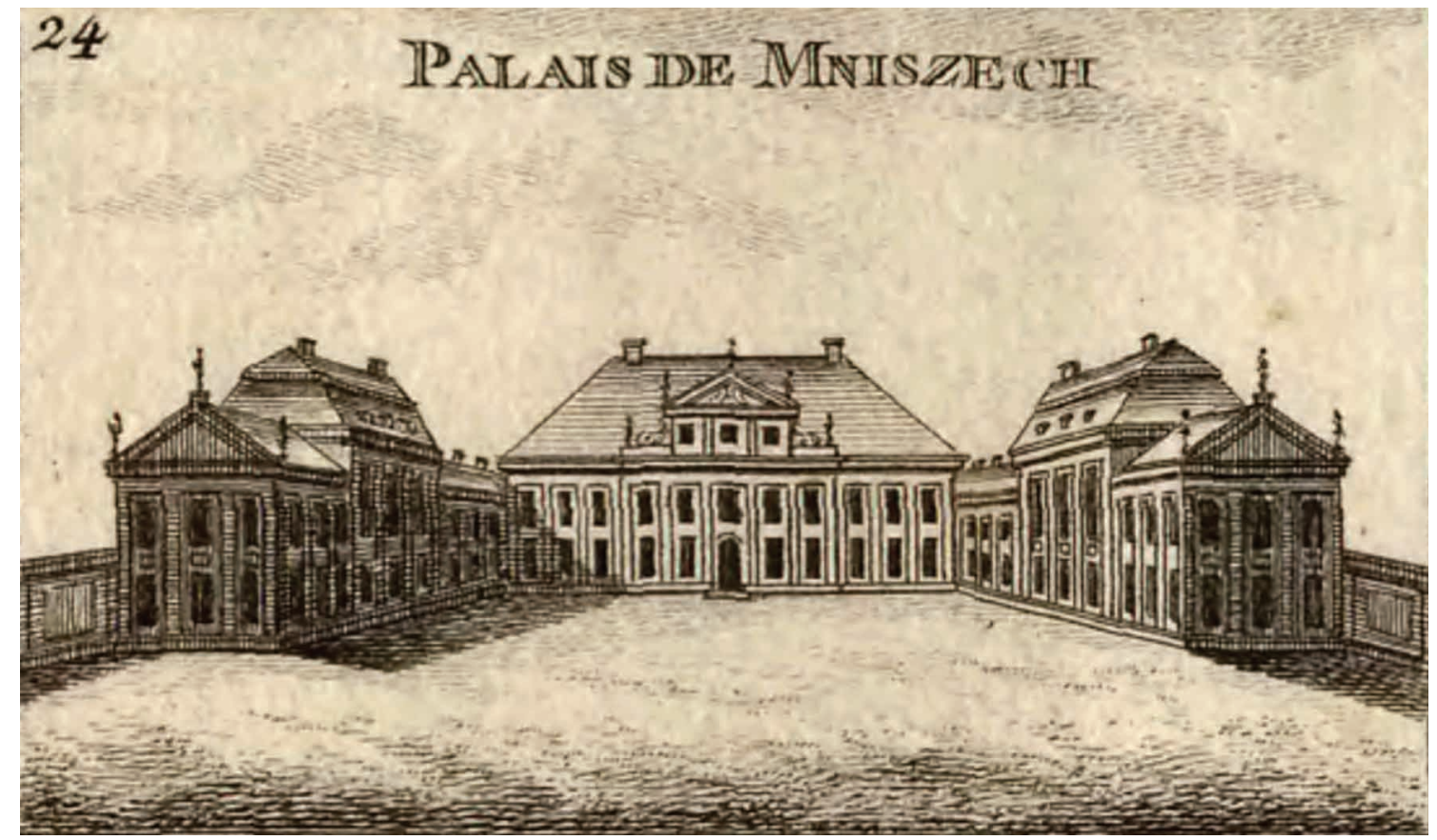

4. Pałac Mniszchów w Warszawie, fragment bordiury Plan de Varsovie Giovanniego Antonia Rizzi-Zannoniego, 1772. Fot. Ślaska Biblioteka Cyfrowa 


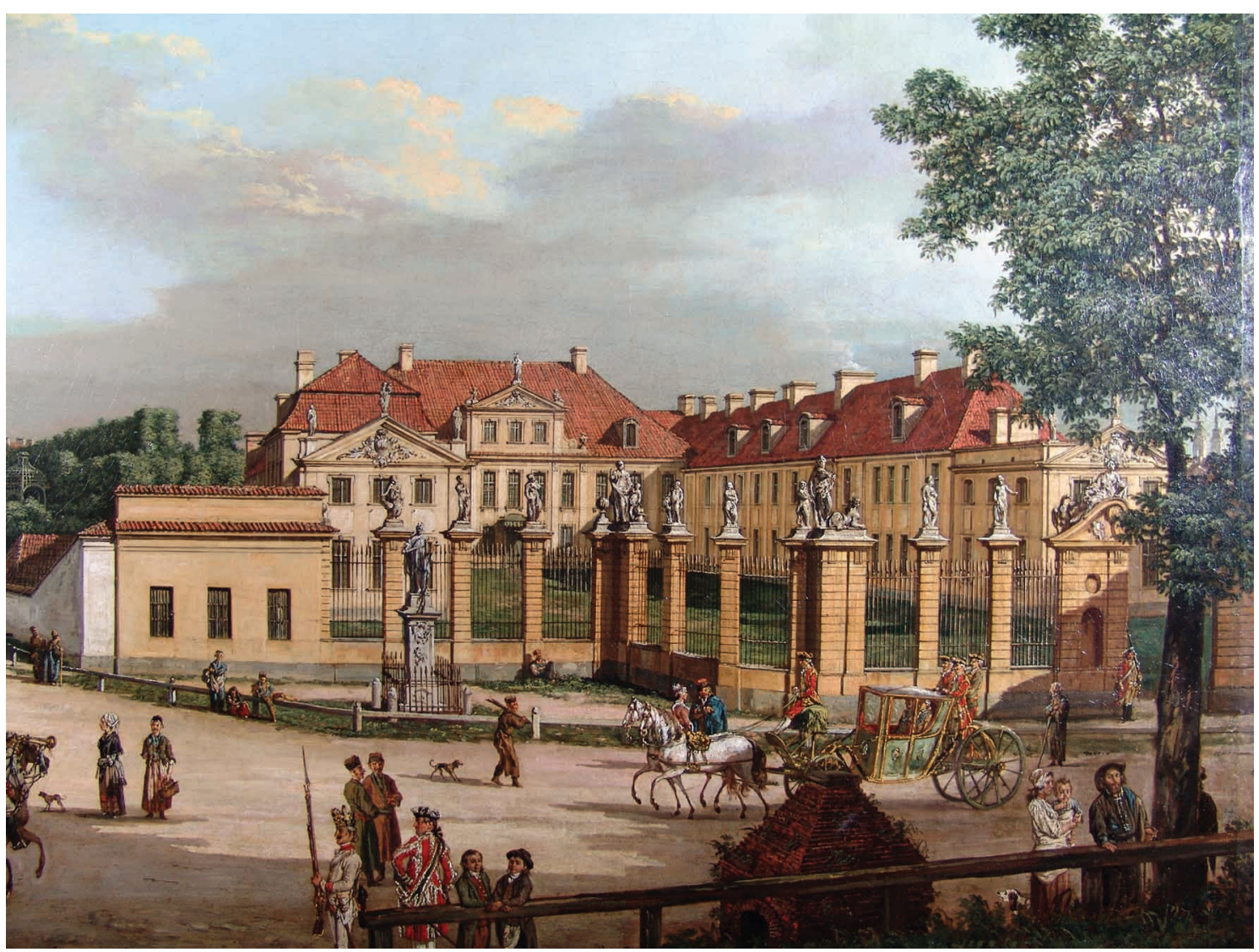

5. Bernardo Bellotto zw. Canaletto, Pałac Mniszchów w Warszawie, 1779, Zamek Królewski w Warszawie. Fot. Zamek Królewski w Warszawie

i elegancji obiektu, który wedle zamysłów poprzednich architektów ,„przypominałby raczej koszary niż rezydencję"18. Do spotkania architekta z Józefem Wandalinem Mniszchem doszło prawdopodobnie w stolicy Saksonii, gdzie marszałek wielki koronny przebywał regularnie. Główną część inwestycji przeprowadzono do 1718 r., jednak prace wykończeniowe trwały jeszcze w 2. połowie lat $20 .{ }^{19}$ Rezydencja Mniszchów zyskała uznanie współczesnych, została zaliczona do najbardziej reprezentacyjnych siedzib magnackich. Uwieczniono ją na panoramach C. F. Hübnera oraz Franza Conrada Schmidta (il. 3), widnieje także (już po zmianie pokrycia dachowego, dokonanej przez syna Józefa, Jerzego Augusta Mniszcha) na bordiurze planu Warszawy Giovanniego Antonia RizziZannoniego (il. 4) oraz na obrazie Canaletta (il. 5).

\section{Forma architektoniczna - korpus główny}

Dwukondygnacyjny pałac Mniszchów przy Senatorskiej został wzniesiony na rzucie prostokąta o wymiarach około $39,5 \times 19,5 \mathrm{~m}^{20}$. Wiązania murów w piwnicach uwidaczniają ich pierwotny obrys, stanowiący środkową, lekko przesuniętą ku wschodowi partię rezydencji. $\mathrm{Na}$ obu kondygnacjach zastosowano system dwóch traktów rozdzielonych

\footnotetext{
$18 \mathrm{ZNiO}, 2697 / \mathrm{II}, \mathrm{k} .173-174$.

${ }^{19}$ BERDECKA, op. cit., s. 7-9.

${ }^{20}$ MADUROWICZ, TYSZKA, op. cit., passim; BARCZYK, „Ambasada...”, s. 99.
} 

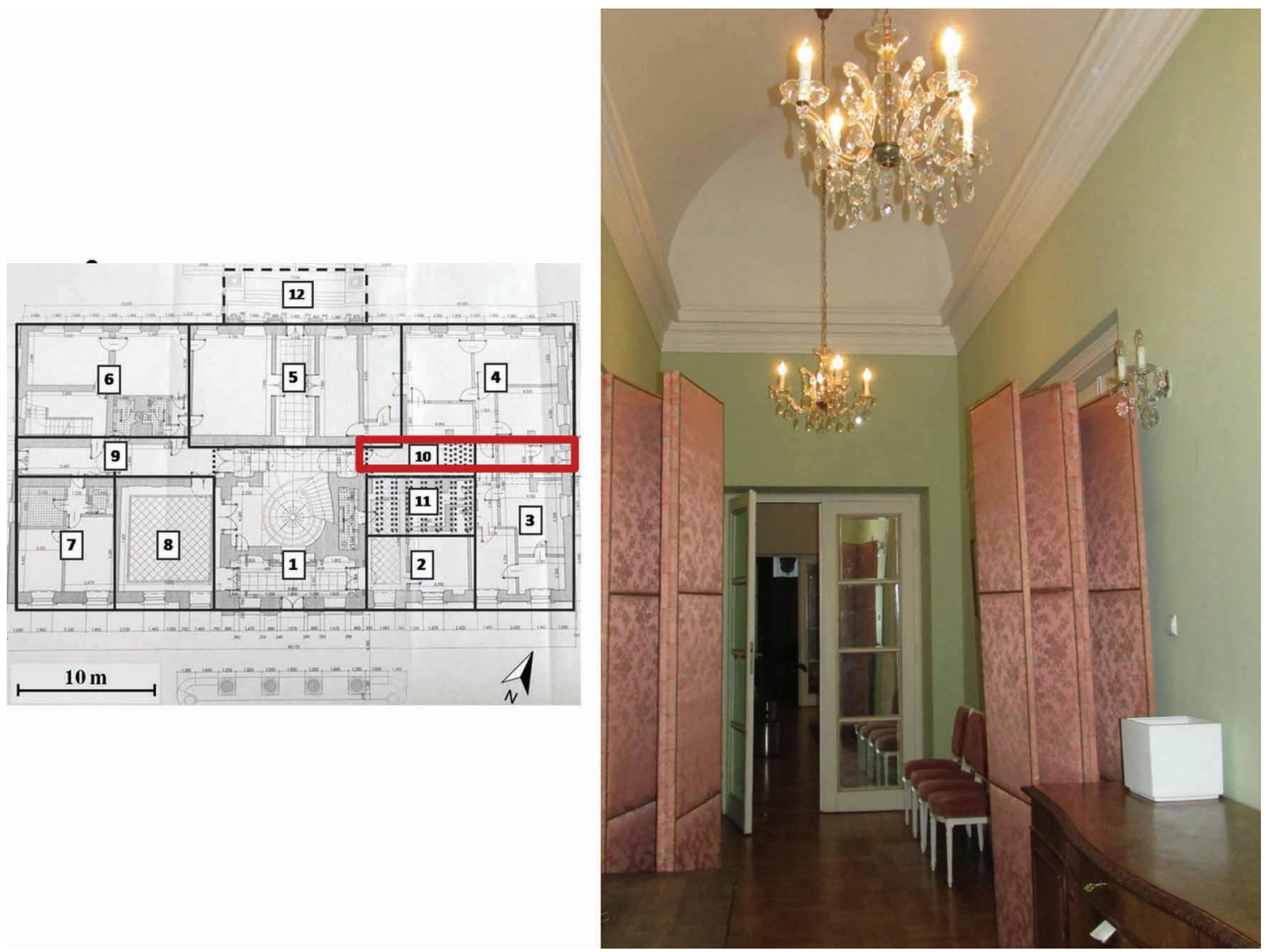

6. Pałac Mniszchów w Warszawie, korytarz na pierwszej kondygnacji. Fot. Alina Barczyk, 2016

centralnym korytarzem, równoległym do głównej fasady (il. 6). Listy z lat 1717-1718, kierowane do Mniszcha przez prowadzącego budowę Sebastiana Rybczyńskiego, obrazują skomplikowany proces inwestycji, której finalizacja opóźniała się głównie z powodu trudności z pozyskaniem wapna oraz braku cegieł, wykupionych do innych „fabryk” warszawskich.

Objęcie funkcji marszałka wielkiego koronnego było możliwe tylko przez najzamożniejszych magnatów - wielkie sumy pochłaniały koszty reprezentacyjne ${ }^{21}$. Jednym z takich wydatków było właśnie przeznaczenie ogromnej kwoty na wzniesienie pałacu przy Senatorskiej. Zatrudnieni przy budowie Niemcy oczekiwali znacznie wyższych wypłat niż polscy rzemieślnicy ${ }^{22}$ - stawki nie tylko znacznie przewyższały kwoty wypłacane przez senatorów, dla których w tym czasie wznoszono rezydencje w Warszawie, lecz także były równe sumom z „fabryk” królewskich ${ }^{23}$. Na wydatki wpływało kilka czynników, decydujących jednocześnie o randze inwestycji i splendorze efektu finalnego. Istniejący

\footnotetext{
${ }^{21}$ Skalę wydatków mających na celu autokreację wizerunku własnego rodu (w przypadku niektórych marszałków nawet przewyższających zyski) prezentuje WIŚNIEWSKI, op. cit., passim.

${ }^{22}$ Pokazałby[m], że polscy cieśle za abrysem prędzey i mniejszy[m] kosztem i tak dobrze jak Niemcy wystawić go mog[a]. Który dach, gdyby ten cieśla Niemiec umart, już by stanqć nie mógt i pałac bez dachu być by musiat jakom powiedział Imci Panu Genrałowi [Münnichowi], srodze się [...] urazit (ZNiO, 2664/I, k. 37).

${ }^{23}$ Fabryka nie ustaje, coraz więcej rzemieślnika przybieram, tylko o płace mam z Niemcami sprzeczkę, którzy sami drogo biorq, na tydzień po dziesięć po dwanaście tynfów, a nigdzie nie płaca na wszystkich fabrykach w Warszawie drożej nad dziesięć złotych szelagami [...], lubo na królewskich robotach tak płaca jak ja dotychczas, ale ja ich nie chcę regulować do królewskiej fabryki, tylko do miejskich i innych senatorskich, których tu jest dosyć, a przy kościelnych tylko po ośm i dziewięć złotych płaca (ZNiO, 2664/I, k. 5); por. POPIOŁEK, op. cit., s. 209.
} 

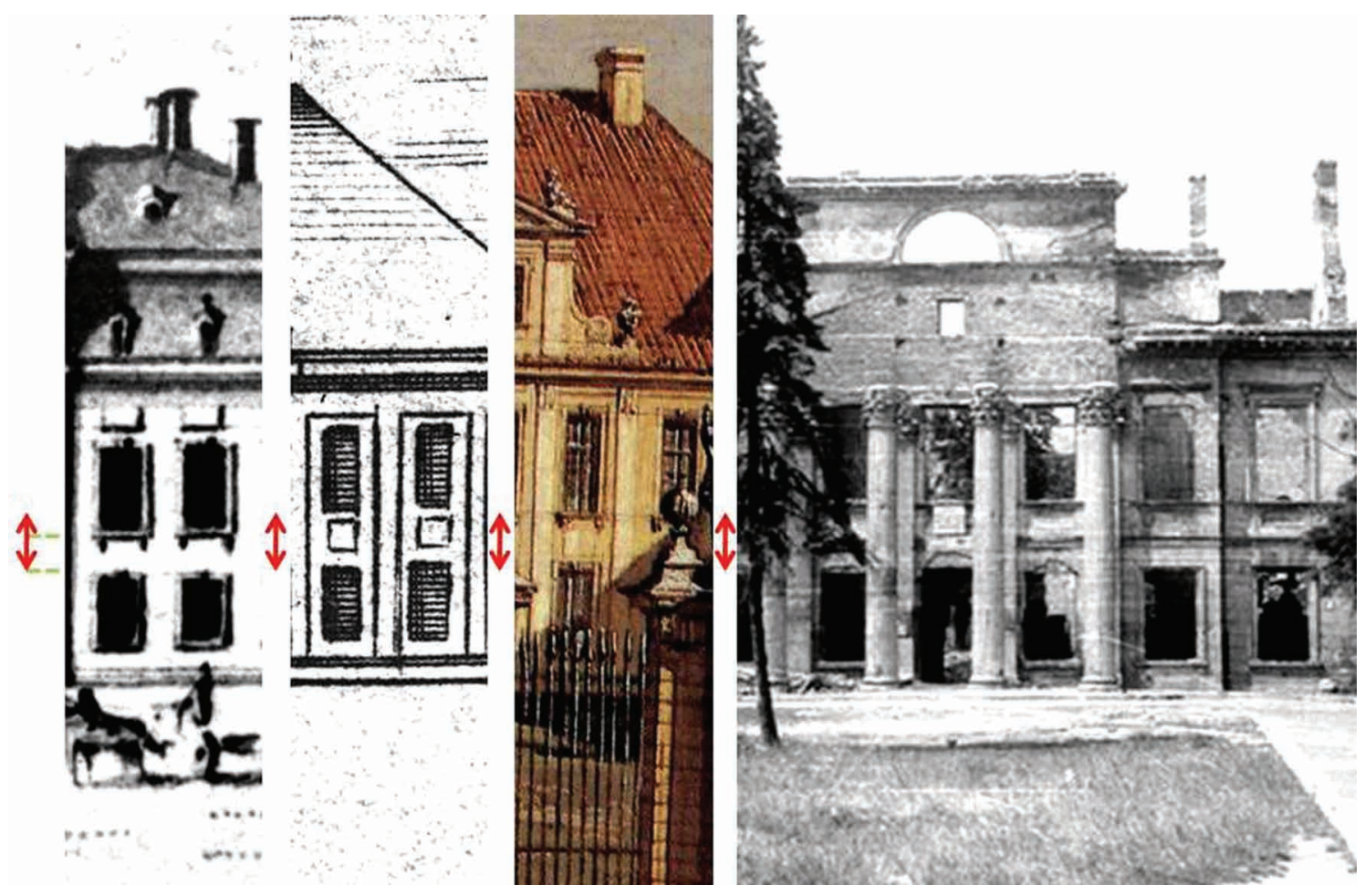

7. Pałac Mniszchów w Warszawie, elewacja. Od lewej: fragment Prospect von Warschau Franza Conrada Schmidta, 1740; fragment Plan de la ville de Varsovie Pierre'a Ricaud de Tirregaille'a, 1762; fragment obrazu Bernarda Bellotta (zob. il. 5), 1779; stan w 1948 r.

wcześniej dwór przynajmniej w dużej części rozebrano wedle zaleceń Münnicha, co pozwoliło na uzyskanie lepszego układu sal i zlikwidowanie ciemnych korytarzy prowadzących do pieców. Niszczono również nowo powstające ściany, jeśli nie spełniały oczekiwań generała, co Rybczyński relacjonował marszałkowi słowami: „,co tydzień albo dwie niedziele robili, to znowu obalali i nowe z fundamentów w inszym miejscu stawiali" 24 .

Inżynier był także odpowiedzialny za projekty oficyn, stajni, kuchni, kordegardy ${ }^{25}$. Przygotował również abrysy pałacowych okien, ,jakich tu mody w żadnym pałacu nie masz" - na drugiej kondygnacji miały one wysokość 3,57 m, zaś nieco mniejszą na parterze. Duży koszt wykonania wszystkich 50 sztuk okien (po 25 na kondygnację) - „250 talarów bitych", obejmował jedynie pracę stolarza. Osobno należało zlecić wyrób szyb i okuć, zrealizowanych również wedle abrysów królewskiego generała. Do wykończenia okien użyto kamienia, z którego wykonano też schody. Zadbano o marmurowe kominy, gdyż „drewniane nie mają tej magnificencyi, co kamienne”26. Materiały sprowadzano z różnych regionów: z Krakowa spławiano Wisłą wapno, z Szydłowca pozyskiwano kamień, w Gdańsku zamówiono marmurową posadzkę ${ }^{27}$.

Elewacje głównego korpusu oraz oficyn miały podziały ramowe. Okna obu kondygnacji zostały zamknięte prosto i ujęte profilowanymi, uszakowymi obramieniami. Na piano nobile były wzbogacone o klucz i wsparte na dwóch konsolach. O charakterze pałacu decydowała dekoracja rzeźbiarska. Osiem bocznych osi elewacji zwieńczono pełnoplastycznymi,

\footnotetext{
${ }^{24} \mathrm{ZNiO}, 2664 / \mathrm{I}, \mathrm{k} .13$.

${ }^{25}$ KWIATKOWSKI, op. cit., s. 13.

${ }^{26} \mathrm{ZNiO}, 2664 / \mathrm{I}, \mathrm{k} .34$.

27 ZNiO, 2664/I, k. 33-34, 46, 52.
} 
pojedynczymi figurami, a dziewiąta personifikację ustawiono na szczycie frontonu. Dekorację dopełniała reliefowa kompozycja heraldyczna, wpisana w pole tympanonu. Analogiczne płaskorzeźby umieszczono w centralnym polu frontonów bocznych oficyn.

Na prospekcie Schmidta z 1740 r. płyciny wieńczą poszczególne osie, podczas gdy na przekazach z drugiej połowy stulecia, chociażby na mapie Ricaud de Tirregaille’a i płótnie Canaletta, oddzielają piętro od parteru (il. 7). Dalsze różnice wyznaczają zmiany wprowadzone podczas przebudowy (naprawa murów, wymiana części belek) prowadzonej pod kierunkiem Jakuba Fontany w czasach Jerzego Augusta Mniszcha: proste przekrycie dachowe oraz połączenie korpusu ze skrzydłem bocznym, wprowadzenie artykulacji pilastrowej na elewacjach ${ }^{28}$. Na widokach z 2. połowy XVIII w. odmiennie prezentuje się także ryzalit poszerzony o dwie osie, łączące się z dolną częścią wypiętrzenia dźwigającego trójkątny fronton za pośrednictwem spływów wpartych na cokole, na którego skrajnych, wyłamanych partiach umieszczono pojedyncze siedzące putta. Brakuje jednak personifikacji, które wcześniej rozmieszczono na linii gzymsu. Ze sceptycyzmem można się odnieść do różnic w rozmieszczeniu płycin. Obecność ram pomiędzy parterem a pierwszym piętrem potwierdzają zarówno przekazy ikonograficzne z 2. połowy XVIII stulecia, wśród nich weduta Canaletta, jak i analiza form architektonicznych pałacu z czasów przed- oraz powojennych ${ }^{29}$. Nie bez znaczenia pozostaje również obecny kształt budowli. Wbrew powszechnie przyjętej opinii, mury magistralne przetrwały w postaci prawie niezmienionej XX-wieczne zniszczenia ${ }^{30}$. Prospect von Warschau Schmidta sugeruje stosunkowo niewielką odległość pomiędzy otworami okiennymi obu kondygnacji, skontrastowaną z większą powierzchnią ściany w górnej partii fasady, gdzie miały znajdować się podziały ramowe. W rzeczywistości proporcje są odwrotne. Nie jest możliwe, by w celu prowadzonej przez Fontanę ,naprawy” konstrukcji, a tym bardziej ze względów czysto estetycznych przemurowywano okna. Ich pierwotny charakter jest widoczny na fotografiach dokumentujących zniszczenia z lat 40. XX w., które odsłoniły wątki cegieł i wiązania murów. Warto również zaznaczyć, że obecność płycin pomiędzy parterem a piano nobile pozwoliła na podkreślenie skali i reprezentacyjności piętra. Analogiczną artykulację można odnaleźć w wielu obiektach rezydencjonalnych, które powstały w pierwszych dekadach XVIII stulecia w kręgu oddziaływania architektury drezdeńskiej. Przywołać można rezydencje królewskie w Warszawie. Dwukondygnacyjny Pałac Saski miał elewacje skrzydeł o piętrach przedzielonych płycinami, a główne wejście usytuowano w trójosiowym, wypiętrzonym ryzalicie z trójkątnym frontonem. Analogiczny sposób opracowania muru powielono na elewacjach Zamku Królewskiego od strony Wisły, do którego dostawiono monumentalne skrzydło, będące pod względem skali i funkcji nowym korpusem. Wedle najnowszych ustaleń, idea stworzenia dodatkowej przestrzeni w Zamku ukształtowała się około 1734-1736 r. ${ }^{31}$ Na jednym z projektów Gaetana Chiave-

\footnotetext{
${ }^{28}$ BERDECKA, op. cit., s. 25-26. Udział Fontany w pracach przy ul. Senatorskiej jest źródłowo potwierdzony w korespondencji z 1754 r.; zob. Aldona BARTCZAKOWA, Jakub Fontana - architekt warszawski XVIII wieku, Warszawa 1970, s. 128.

${ }^{29}$ Stan po II wojnie światowej poświadczają dokumentacje fotograficzne, ekspertyzy i projekty odbudowy (m.in. BRUKALSKI, op. cit., passim) oraz wnioski z analizy in situ przeprowadzonej przez Annę Berdecką i Stanisława Lorentza (BERDECKA, op. cit., passim).

${ }^{30}$ Por. przyp. 8.

${ }^{31}$ Wyniki najnowszych badań nad dziejami przekształceń rezydencji prezentował Jakub Sito podczas seminariów naukowych organizowanych na Zamku Królewskim: Przemiany Zamku Królewskiego w Warszawie za panowania Augusta II, 8 czerwca 2015; Przemiany architektoniczne Zamku Królewskiego w Warszawie za panowania Augusta III, 8 grudnia 2016.
} 

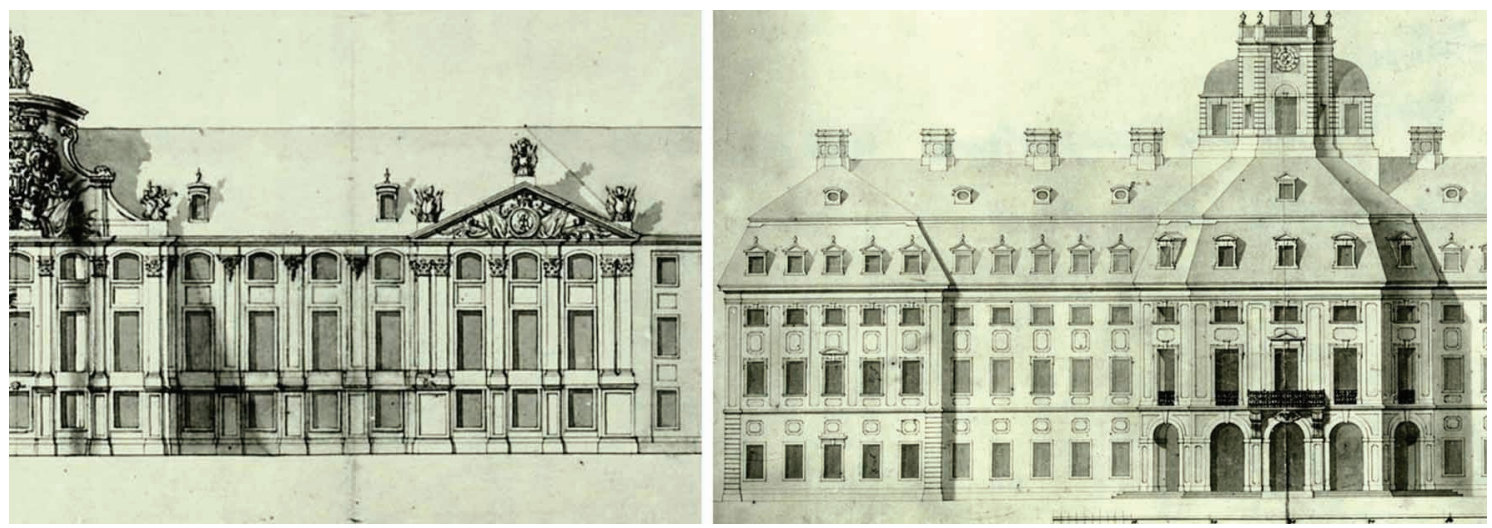

8. Od lewej: Gaetano Chiaveri, projekt przebudowy pótnocno-wschodniego skrzydta Zamku Królewskiego w Warszawie, przed 1740. Fot. Sächsisches Hauptstaatsarchive, Drezno; Johann Christoph von Naumann, zamek Hubertusburg w Wermsdorfie, 1721, elewacja. Fot. Sächsisches Hauptstaatsarchive, Drezno

riego dekorację nowego korpusu ograniczono do podziałów ramowych z międzykondygnacyjnymi płycinami o wykroju czworokąta i skromnych obramień otworów okiennych, które na wszystkim trzech poziomach zostały zamknięto prosto ${ }^{32}$. $\mathrm{Z}$ dachu wyprowadzono pojedyncze lukarny. Płyciny zastosowano także pomiędzy piano nobile a drugim piętrem dawnych skrzydeł i pawilonów, uzyskano jednak odmienne efekty za sprawą artykulacji wielkoporządkowej, dzięki której nastąpiło większe zróżnicowanie płaszczyzn. Przekaz ideowy dopełniły reliefy i pełnoplastyczne rzeźby. Twórcą zdobień był Johann Georg Plersch - artysta wiązany z dekoracją warszawskiego pałacu Mniszchów ${ }^{33}$. Przebudowę rezydencji Augusta II finansowano wyłącznie z funduszy skarbu Rzeczypospolitej, w odróżnieniu od Nowego Zamku w Grodnie, wznoszonego z funduszy saskich, czyli pochodzących bezpośrednio z Drezna. Pomimo nazwy grodzieńska budowla pod względem funkcjonalnym i architektonicznym bliższa była pałacowi niż zamkowi. Fabrykę warunkowała zasada organizacji w mieście co trzeciego sejmu. Projekt rezydencji władcy wykonał Carl Friedrich Pöppelmann, wprowadzając po raz kolejny analogiczne podziały ramowe ${ }^{34}$. Funkcje polityczne Grodna przyczyniły się do rozwoju miasta. Józef Wandalin Mniszech w liście z 1726 r., pisanym po przybyciu na sejm, wspominał, że w mieście „dworów pięknych pobudowano wiele”.

Na lata 1721-1731/1732 datowane są rysunki projektowe Johanna Christopha von Naumanna dla pałacu myśliwskiego Augusta II Hubertusburg w Wermsdorfie ${ }^{35}$. Szkice fasady ukazują prosto zamknięte okna i płyciny międzykondygnacyjne (il. 8). Parter od piano nobile oddzielono dodatkowo gzymsem. Na późniejszych projektach, wykonanych w 2. połowie lat 30. i w latach 40. XVIII w. przez Johanna Christopha Knöffla, widoczne są

\footnotetext{
${ }^{32}$ Sächsische Landesbibliothek - Staats- und Universitätsbibliothek Dresden, d. 30117894.

${ }^{33}$ Jak zauważył Jakub Sito, Mniszech jako marszałek wielki koronny był zapewne odpowiedzialny za pilnowanie ,fabryki” królewskiej; zob. przyp. 31.

${ }^{34}$ Analogie wykazuje też ukształtowanie dziedzińca, ujętego bocznymi skrzydłami pałacu.

${ }^{35}$ Zbiór rysunków Naumanna znajduje się w Landesamt für Denkmalpflege Sachsen, Planarchiv w Dreźnie: Signatur/ Inventar-Nr.: M 30 B. Z bogatej literatury dotyczącej niniejszej rezydencji wspomnieć można chociażby artykuł Steffena Delanga omawiający projekty oraz dzieje budowy; zob. Steffen DELANG, ,Seine Baugeschichte und Seine Stellung innerhalb der eurpäischen Schlossbaukunst des 18. Jahrhunderst", [w:] Die königliche Jagdresidenz Hubertusburg und der Frieden von 1763, red. Dirk SYNDRAM, Dresden 2013, s. 31-46.
} 

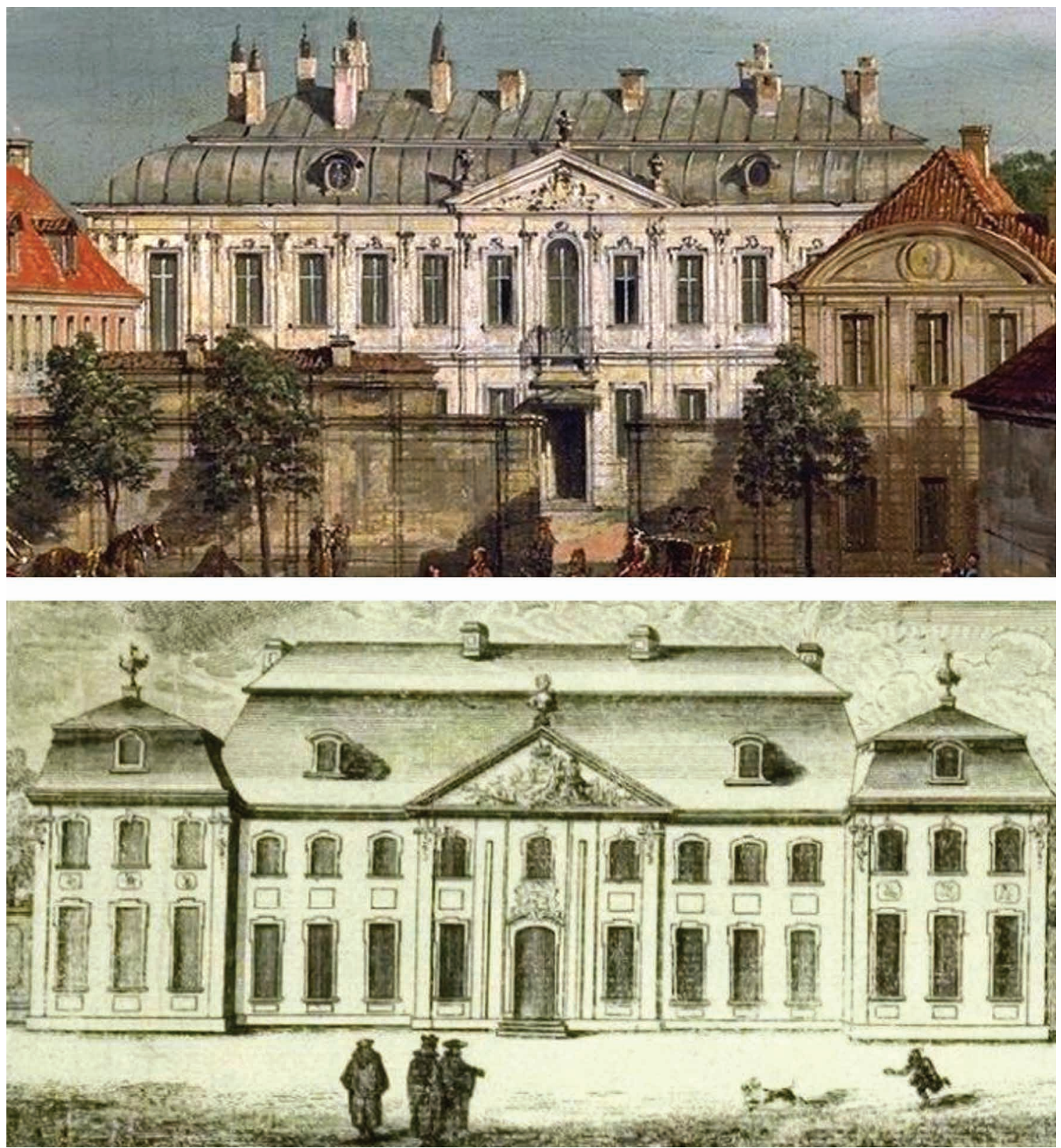

9. Od góry: pałac Błękitny w Warszawie, fragment obrazu Bernarda Bellotta Pałac Błękitny, 1779, Zamek Królewski w Warszawie; pałac Prymasowski w Warszawie, fragment Plan de la ville de Varsovie Pierre'a Ricaud de Tirregaille'a, 1762

bogatsze obramienia otworów okiennych i profile płycin ${ }^{36}$. Jedna z wersji (1743) zakładała także połączenie sal pierwszego i drugiego piętra (z wyłączeniem skrajnych ryzalitów) oraz wprowadzenie wysokich smukłych okien, które miały być zamknięte półkoliście. W efekcie płyciny przeniesiono w górną partię budowli, wieńcząc nimi poszczególne osie, co jest zbieżne z ukształtowaniem lica muru pałacu Mniszchów przy Senatorskiej na prospekcie Schmidta z 1740 r. Przywołana wcześniej analiza bryły wyklucza jednak możliwość występowania tego rozwiązania w warszawskiej siedzibie marszałka wielkiego koronnego. Szkic Knöffla z 1743 r. jest o blisko ćwierć wieku późniejszy niż czas powsta-

${ }^{36}$ Projekty w zbiorach drezdeńskiego Landesamt für Denkmalpflege Sachsen, Planarchiv; Signatur/Inventar-Nr.: M 30; por. DELANG, op. cit., s. 41. 

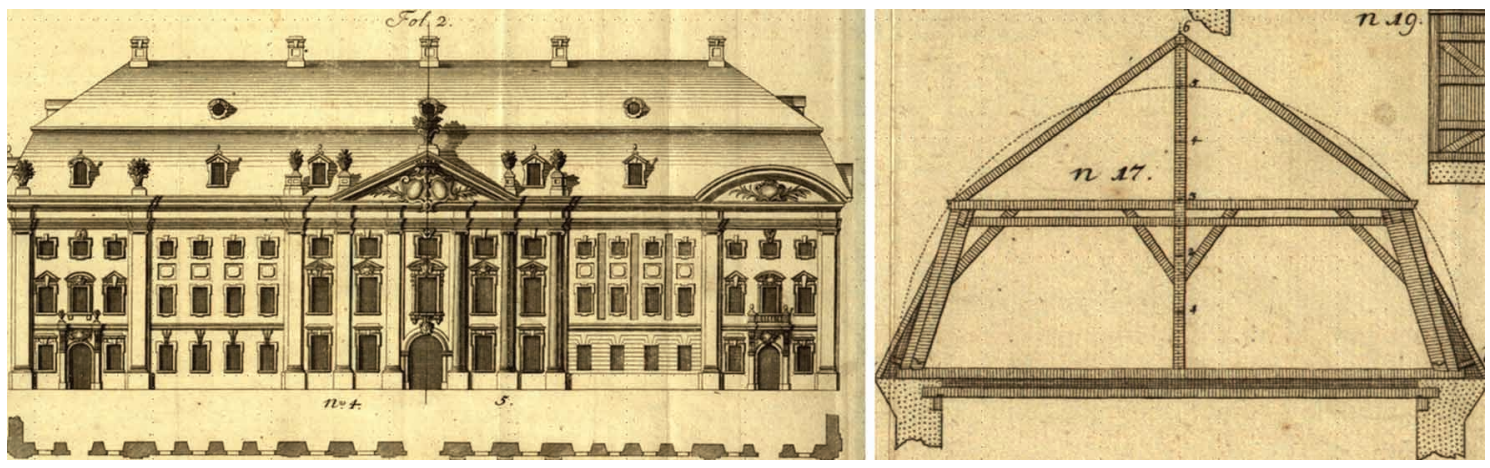

10. Przekrój więźby dachu mansardowego, ilustracja z Architectura Practica. Die würckliche und tüchtige Bau-Kunst, so wohl bey Palatiis, als auch Bürgerlichen Häusern Johanna

Christopha von Naumanna (Budißin 1736). Fot. domena publiczna

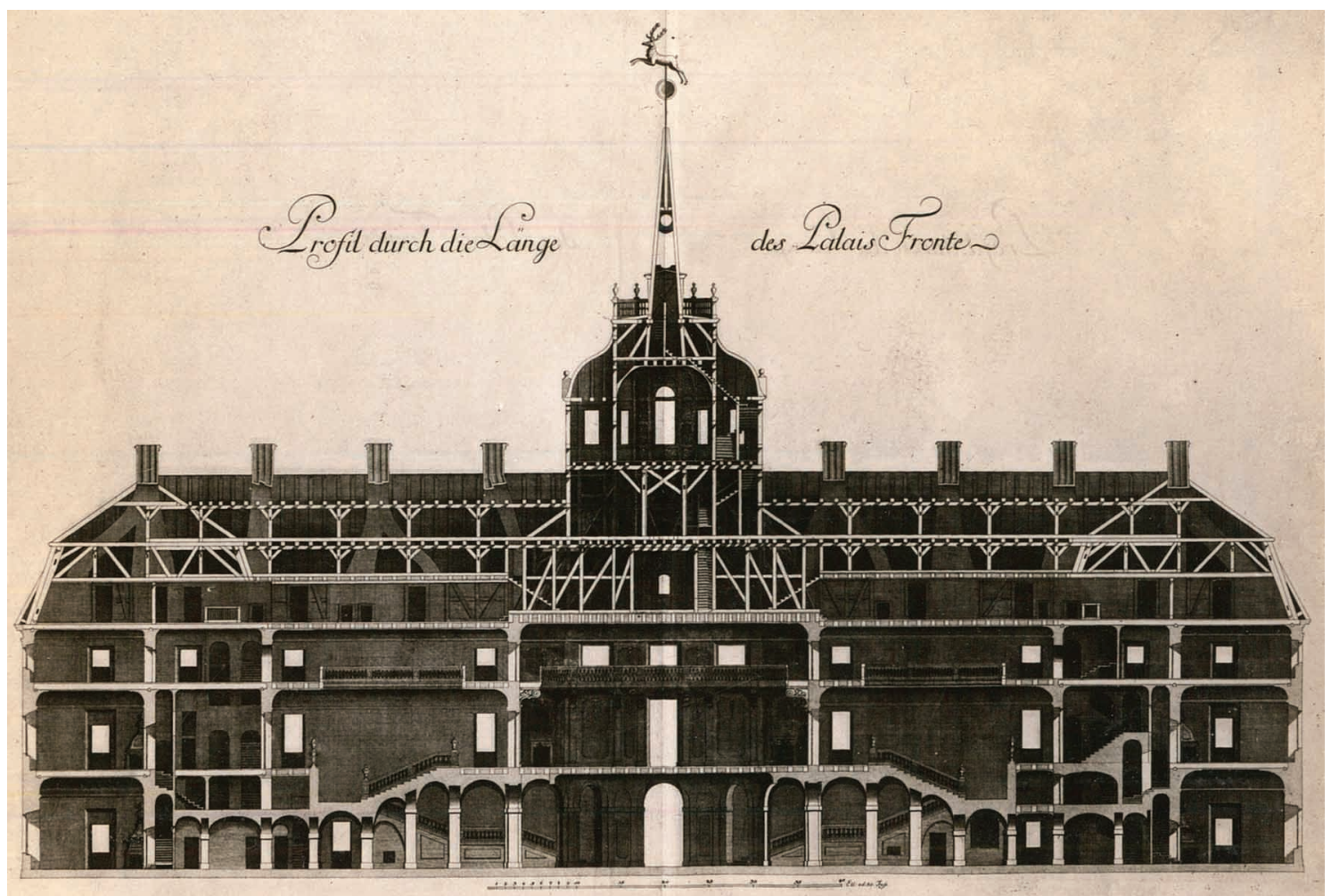

11. Johann Christoph von Naumann, zamek Hubertusburg w Wermsdorfie, 1727, przekrój. Fot. Sächsische Landesbibliothek, Drezno

nia Hubertusburga. Ogólny wyraz bryły pałacu Wettynów pozostał jednak zgodny z charakterem nadanym mu we wcześniejszej fazie budowy.

Siedziby monarchy pozostawały wzorcem dla magnatów, przyczyniając się popularyzacji stosowanych w nich układów i sankcjonując rozwiązania, które zyskały uznanie w poprzednich dekadach. Rozwój form związanych z saską genezą występował częściej, ponieważ w „fabrykach” wielokrotnie zatrudniano architektów i budowniczych pochodzących z Saksonii bądź zdobywających wykształcenie na terenach niemieckojęzycznych ${ }^{37}$.

${ }^{37}$ O środowisku architektoniczno-budowlanym Warszawy czasów saskich zob. HENTSCHEL, op. cit., passim; Słownik architektów i budowniczych środowiska warszawskiego XV-XVIII wieku, red. Paweł MIGASIEWICZ, Hanna OSIECKA-SAMSONOWICZ, Jakub SITO, Warszawa 2016, passim. 


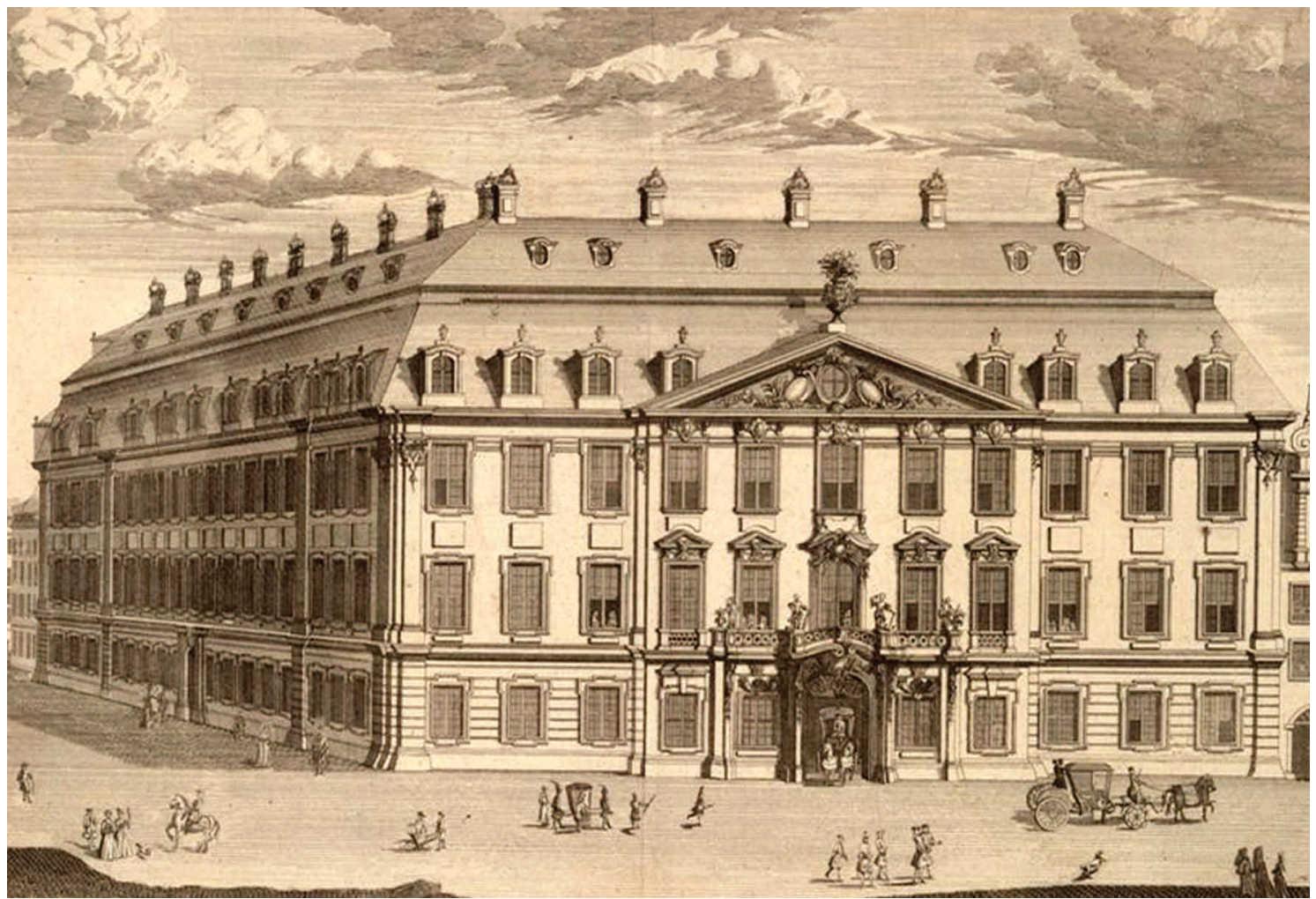

12. Matthäus Daniel Pöppelmann, Widok pałacu Flemminga-Sułkowskiego w Dreźnie, miedzioryt Johanna Georga Schmidta, przed 1736. Fot. Sächsische Landesbibliothek, Drezno

Synonimiczny sposób ukształtowania elewacji udokumentowano na bordiurze planu Warszawy Ricaud de Tirregaille'a, gdzie przedstawione zostały pałace Godzkich, Branickich czy rezydencja prymasa Stanisława Szembeka. Zbliżoną artykulację, choć wprowadzoną do obiektów o większej liczbie kondygnacji, zastosowano w górnej partii pałacu Radziwiłłów oraz w drezdeńskiej siedzibie Flemminga-Sułkowskiego, co obrazuje miedzioryt według rysunku Matthäusa Daniela Pöppelmanna ${ }^{38}$. Architekt ten, którego dzieła bez wątpienia wpłynęły na twórczość Burkharda Christopha Münnicha, był także autorem projektów drezdeńskiego pałacu Jacoba Heinricha von Fleminga (nazywanego Holenderskim później Japońskim) ${ }^{39}$. Co znamienne, w wymienionych budynkach płyciny rozdzielają przedostatnie i ostatnie piętro, nigdy zaś nie wieńczą fasady.

Najbardziej nowatorskim rozwiązaniem w pałacu Mniszchów przy Senatorskiej było wprowadzenie mansardowego dachu, poświadczającego zdolności projektowe Münnicha oraz aspiracje właściciela. Na podkreślenie zasługuje ówczesna świadomość prekursorstwa konstrukcji. Rybczyński niejednokrotnie relacjonował w listach, że w obiekcie widoczna jest „cudzoziemska moda”, fabrykę prowadzono „według trybu saskiego”, a sam dach mansardowy odczytywany był przez obserwujących budowę magnatów jako bliski pałacom w Saksonii i całkowicie nieznany w architekturze ziem polskich. Powstawanie rezydencji wzbudzało zainteresowanie przedstawicieli ważnych rodów, jak chociażby referendarza koronnego Stefana Potockiego i jego małżonki, którzy „przejeżdżając [...]

\footnotetext{
${ }^{38}$ Datowany ante 1736 Ansicht vom Palais Flemming-Sulkowski in Dresden ze zbiorów Sächsische Landesbibliothek - Staats- und Universitätsbibliothek Dresden, Signatur/Inventar-Nr.: SLUB/KS B1682.

39 Zob. Kristina FRIEDRICHS, Stefan HERTZIG, Henrik KARGE, Das Japanische Palais in Dresden, Petersberg 2019.
} 


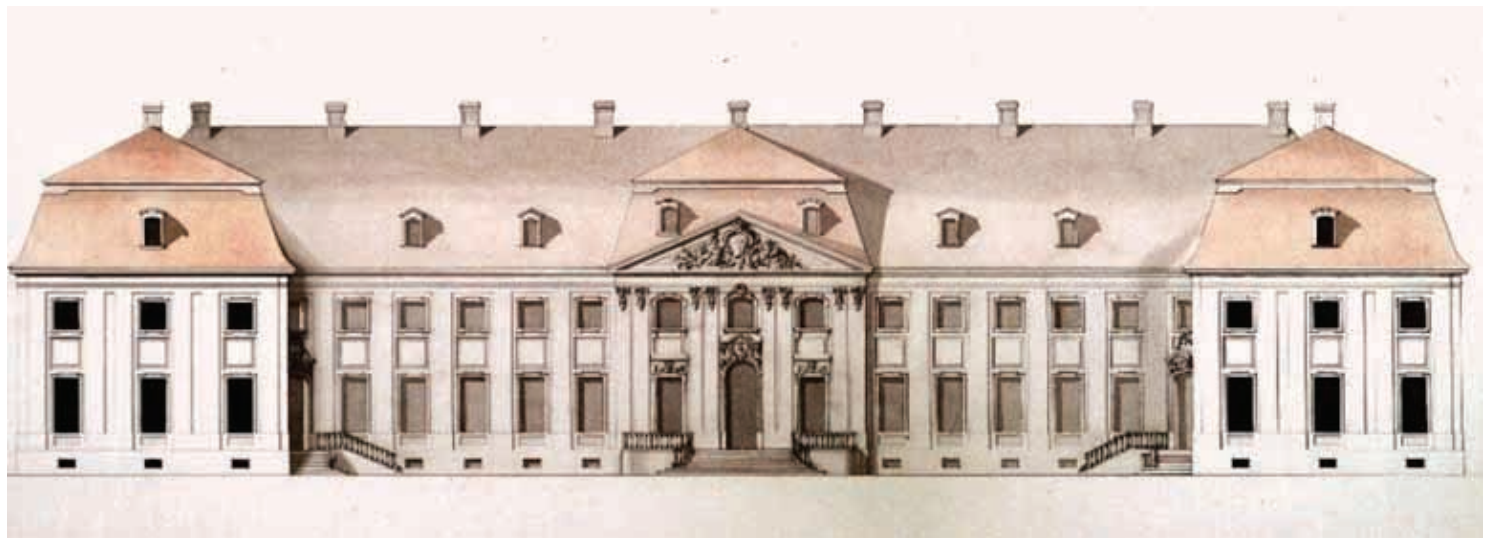

13a. Nowy Zamek w Grodnie. Fot. domena publiczna

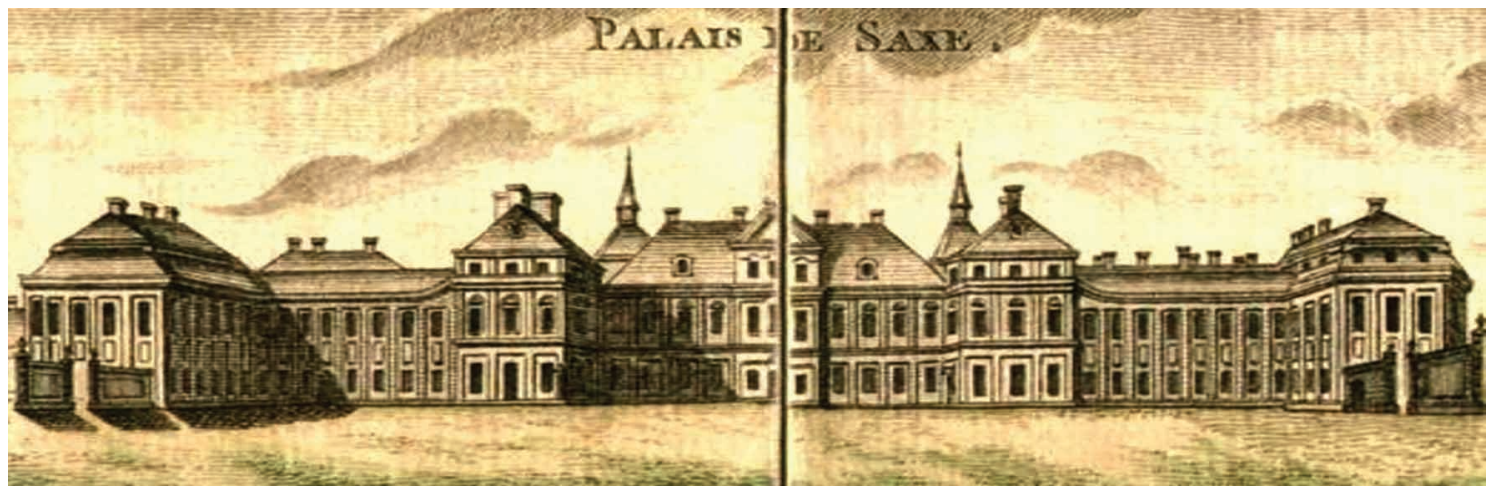

13b. Pałac Saski w Warszawie, fragment Plan de Varsovie Giovanniego Antonia Rizzi-Zannoniego, 1772.

Fot. Ślaska Biblioteka Cyfrowa

przypatrowali się murom i dziwowali się, że tak prędko stanęły, jakoż dosyż wielka machina" ${ }^{40}$ ). Pierwsze efekty prac już in statu nascendi były cenione przez współczesnych przedstawicieli elit ${ }^{41}$.

Prace nad dachem, prowadzone w latach 1717-1718, były tym bardziej zauważalne, że konstrukcję układano na dziedzińcu, dzięki czemu możliwe było obrabianie materiałów i wprowadzanie korekt (np. w kącie nachylenia, który należało dostosować do lokalnych warunków klimatycznych). Na konieczność uwzględnienia obfitych opadów śniegu wskazał w marcu 1718 r. niemiecki magister cieśla, zatrudniony w tym samym czasie przy budowie królewskiej żupy ${ }^{42}$. Zgodnie z zapewnieniem, że „drzewa i kosztów żałować nie będę" ${ }^{43}$, dostarczano nawet trudno dostępne materiały (problematyczne okazało się sprowadzanie w drugiej połowie listopada $1717 \mathrm{r}$. belek długości blisko $17 \mathrm{~m}^{44}$ ).

\footnotetext{
40 ZNiO, 2664/I, k. 28.

${ }^{41}$ Już w lipcu 1717 r. Rybczyński zapewniał, iż „piękna dyspozycyja, wszyscy przyznają” (ZNiO, 2664/I, k. 13).

42 Tenże magister [cieśla niemiecki] powiedział mi, że dachu trzeba zniżyć na trzy łokcie blisko, a jak rozumiał, że go trzeba przyczynić dla śniegów, które na dachach, gdy niskie są, niespadziste w lód się obracają i po tym przez dachówki przeciekają" (ZNiO, 2664/I, k. 37).

${ }^{43} \mathrm{ZNiO}, 2664 / \mathrm{I}$, k. 28.

${ }^{44} \mathrm{~W}$ liście do Mniszcha Rybczyński relacjonował: Cieśla nowa mi trudność zadał podawszy mi regestr drzewa, jakiego jeszcze potrzebuje sztuk 460, między którym drzewem potrzebuje belek dtugich na łokci trzydzieści, grubych na ośm calów, a takiego dhugiego drzewa tu trudno dostać [...], mi się zda, że mię tylko chciał odstraszyć takim regestrem, abym mu nie naglit o ten dach, bo jest drzewa caty dziedziniec (ZNiO, 2664/I, k. 28).
} 
Prawdopodobnie dach tworzony wedle abrysów Münnicha był pierwszym przykładem tego rodzaju konstrukcji w stolicy Polski, poprzedzającym powstanie przekryć położonego naprzeciwko pałacu Błękitnego, rezydencji Bielińskiego, Brühla, jak i pałacu Prymasowskiego (il. 9) ${ }^{45}$. Dachy mansardowe miały genezę francuska, jednak na ziemiach niemieckich dokonano ich reinterpretacji - w nowej redakcji uzyskały zmieniony kąt nachylenia oraz charakter korespondujący z charakterystycznym dla sztuki saskiej sposobem komponowania brył i opracowywania dekoracji architektonicznej. W Warszawie Münnich posłużył się drezdeńską redakcją form, znaną z autopsji zarówno samemu inżynierowi, jak i właścicielowi rezydencji. Powiększenie powierzchni użytkowej stanowiło jeden z atutów przekryć mansardowych (il. 10) ${ }^{46}$. Powyższy aspekt dobrze ilustruje rysunek Johanna Christopha Naumnna z 1727 r. (Sächsische Landesbibliothek), na którym ukazano przekrój wspomnianego wyżej pałacu Huberstusburg (il. 11). Konstrukcja dachowa stanowi blisko 40\% wysokości całego budynku od przyziemia do kalenicy. Mansardy były powszechne w projektach Matthäusa Daniela Pöppelmanna z dwóch pierwszych dekad XVIII stulecia. Tego rodzaju przekrycie umieszczono między innymi na pałacu Flemminga-Sułkowskiego (il. 12). Spośród innych, również wcześniej wspomnianych obiektów, dla których zaprojektowano analogiczne zadaszenia, przywołać należy królewskie siedziby - pałac Hubertusburg oraz Nowy Zamek w Grodnie (il. 13a). W drugiej z rezydencji dach mansardowy ograniczono jednak do środkowego ryzalitu i skrzydeł bocznych. Na szczególną uwagę zasługuje drezdeński pałac Holenderski Flemminga. Przedstawiający go sztych Johanna Rudolpha Fäscha powstał w roku 1715, a więc najwyżej dwa lata przed rozpoczęciem prac przy siedzibie Mniszcha przez Münnicha ${ }^{47}$. Z rezydencją Mniszcha łączy go zarówno ukształtowanie głównego korpusu, jak i sposób komponowania przestrzeni ceremonialnej - dziedzińca ujętego z dwóch stron wolnostojącymi oficynami. Teren posesji ogrodzono parkanem o wyłamującej się linii. Część frontową stanowiły ażurowe metalowe przęsła przedzielone murowanymi słupkami, na których umieszczono pełnoplastyczne rzeźby figuralne. Tę dekoracyjną, akcentującą rangę rezydencji koncepcję powielono w warszawskiej siedzibie marszałka.

\section{Otoczenie pałacu - ogród i dziedziniec paradny}

Dziedziniec pałacu mógłby stać się przedmiotem odrębnego opracowania. Przy omawianiu źródeł inspiracji czytelnych w architekturze rezydencji Mniszcha nie sposób jednak nie wspomnieć o kilku wybranych analogiach pokazujących popularność i sposób kreacji tego typu rozwiązań. Istotna i stale aktualna była rola placów przed główną siedzibą, którą uwzględniono już w pałacu wersalskim. Wpływ dziedzińca na ekspozycję i recepcję bryły oraz na rozwój ceremoniału trafnie oddają materiały ikonograficzne, wśród nich sztychy i akwarele Israëla Silvestre'a (1621-1691). Osiowość założeń podkreślano

\footnotetext{
${ }^{45}$ HENTSCHEL, op. cit., passim.

${ }^{46}$ Generał Münnich, pomysłodawca korekty abrysów przygotowanych przez innych budowniczych i zmiany sposobu tradycyjnego przekrycia na dach mansardowy, swoją propozycję uzasadniał zarówno względami estetycznymi, ekonomicznymi, jak i funkcjonalnymi. W listach deklarował, że dodatkowa przestrzeń może być wykorzystana do suszenia prania, a nowatorskie rozwiązania konstrukcyjne zapewnią oszczędność i przyspieszą tempo „fabryki” (ZNiO, 2697/II, passim). W praktyce kwestia czasu i finansów przedstawiała się wręcz przeciwnie (ZNiO, 2664/I, passim).

${ }^{47}$ Münnich dokonał zmian we wcześniejszym projekcie. Budowę pałacu rozpoczęto więc najpewniej w $1716 \mathrm{r}$. Zachowana korespondencja jednoznacznie potwierdza, że zastosowanie nowatorskich rozwiązań konstrukcyjnych i estetycznych było zasługą królewskiego generała; por. ZNiO, 2697/II, s. 174; ZniO, 2664/I, passim.
} 


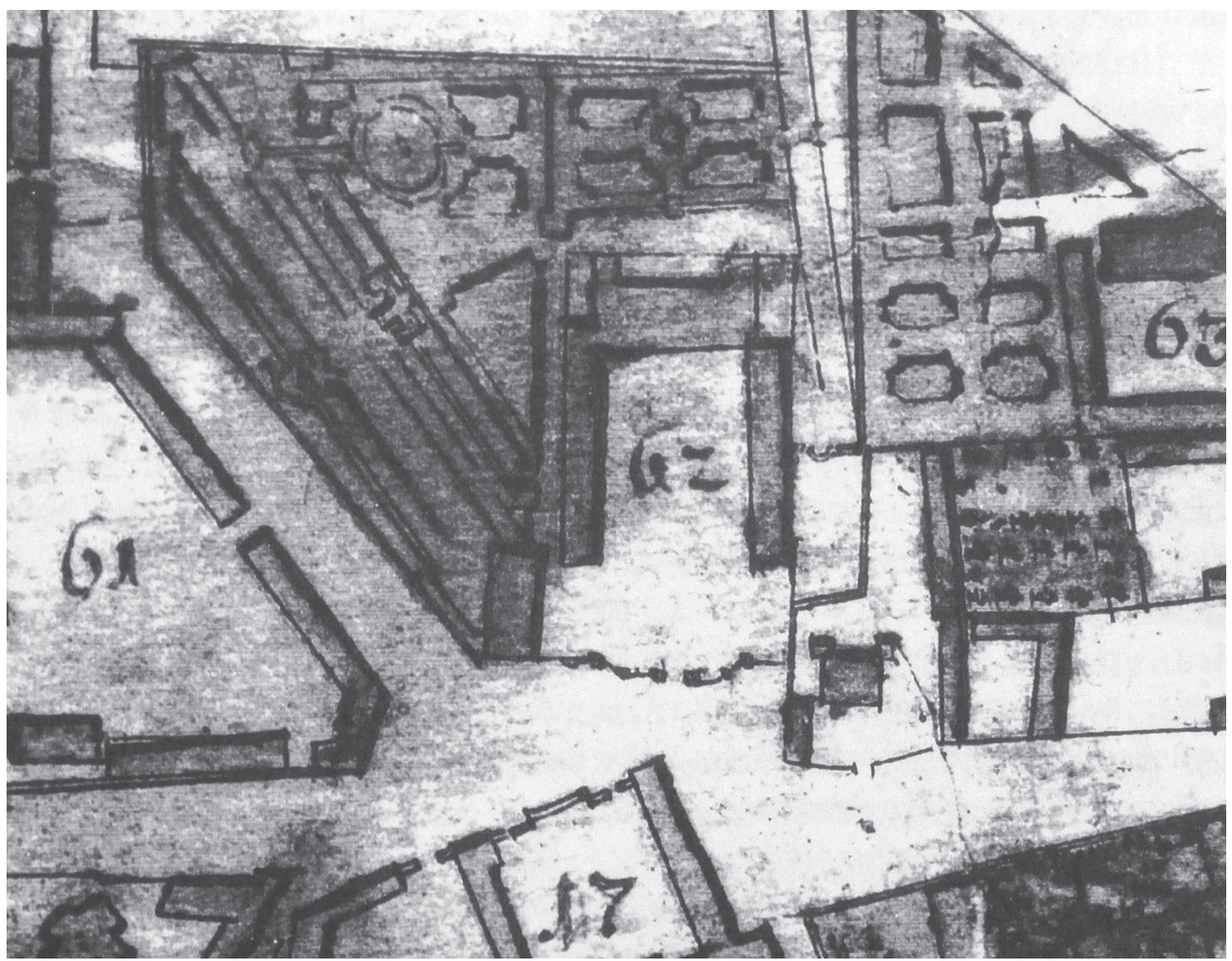

14. Pałac Mniszchów na planie Warszawy Carla F. Hübnera, 2. połowa lat 30. XVIII w. Fot. Sächsisches Hauptstaatsarchive, Drezno

przez centralnie usytuowaną bramę, wkomponowaną w linię ogrodzenia. Redakcja form w kręgu architektury środkowoeuropejskiej w pierwszych dekadach XVIII w. opierała się często na zamykaniu trzech boków czworobocznego dziedzińca trzema skrzydłami pałacu. W omawianej siedzibie Mniszcha, podobnie jak w pałacu Holenderskim, budynki wydzielające obszar pozostawały niezależne (il. 14). W przypadku skrzydeł zintegrowanych mamy do czynienia $\mathrm{z}$ odrębną problematyką architektoniczną, która w tym miejscu musi zostać pominięta. Należy jednak podkreślić wspólną cechę, opartą na sposobie akcentowania placu przed głównym korpusem. Pod tym względem interesująco prezentował się Schloss Hoff z mansardowym nakryciem bocznych skrzydeł (przekształcany od 1725), pałace w Augustusburgu czy Hubertusburg w Wermsdorfie, dokąd jesienią przenosił się dwór Augusta II. Trzema skrzydłami ujęto także dziedziniec rezydencji wilanowskiej. Zwłaszcza w pałacach miejskich dziedzińce starano się poprzedzać parkanem, będącym wyraźną granicą między ulicą a przestrzenią reprezentacyjną przynależną do właściciela. Do ciekawszych rozwiązań tego typu należały pałace z obszaru niemieckojęzycznego, w tym wiedeński Gartenpalast Harrach, którego oba dziedzińce poprzedzono parkanami z monumentalną bramą. Nie można również pominąć wspomnianej już rezydencji królewskiej w Grodnie, w którym front dziedzińca zamknięto ogrodzeniem z boniowanymi słupkami oraz dekoracją rzeźbiarską.

W świetle powyższych faktów czytelny staje się nowatorski charakter głównego korpusu siedziby marszałka wielkiego koronnego, gdzie forma architektoniczna stanowiła 


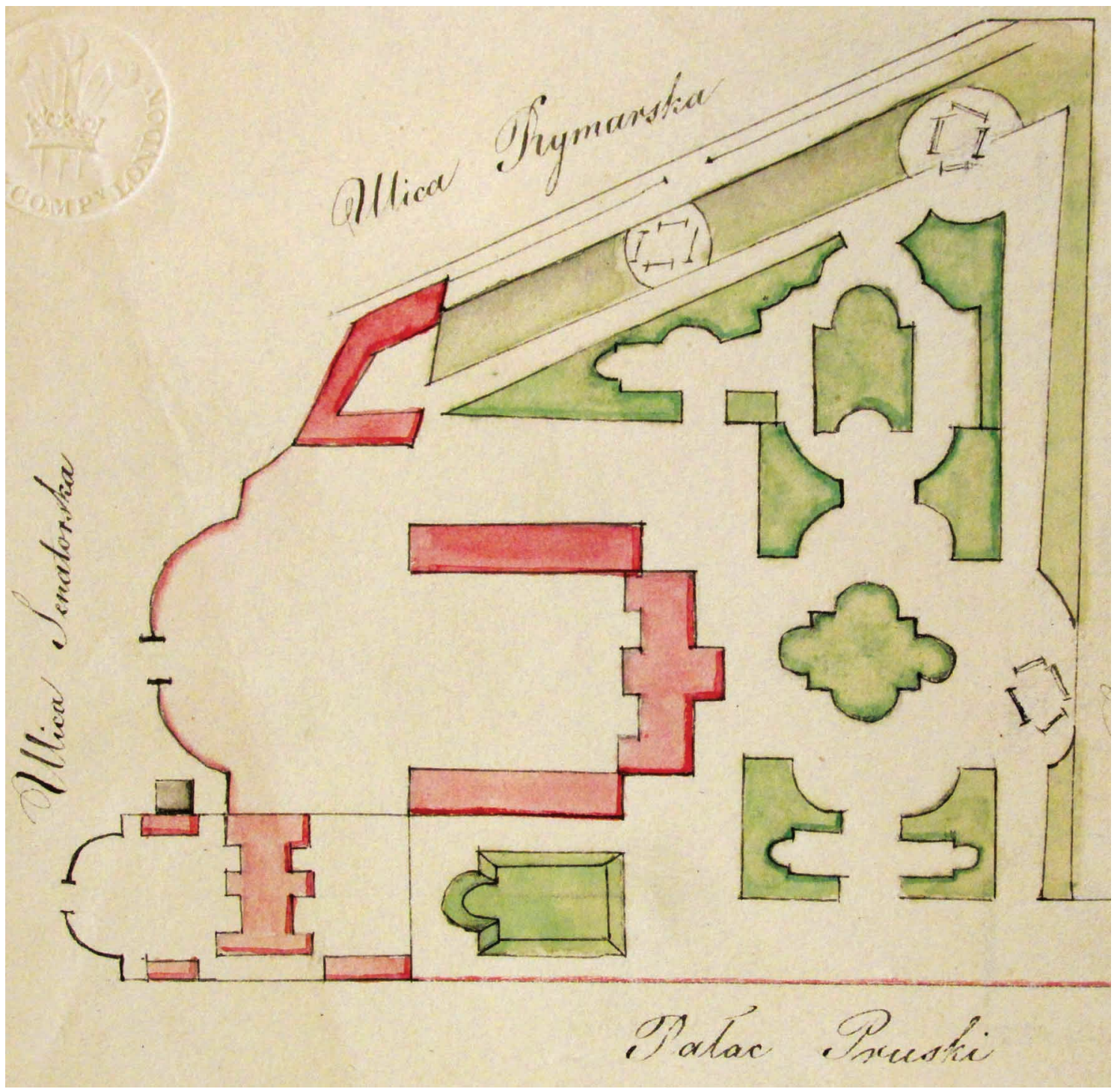

15. Plan założenia pałacowo-ogrodowego przy ul. Senatorskiej w Warszawie, ok. 1816, Warszawa, Muzeum Narodowe, Rys. Pol. 15642. Fot. Muzeum Narodowe w Warszawie

odpowiedź na potrzebę sankcjonowania pozycji właściciela i sprawowania funkcji politycznych. Równie ważna była opracowana przez Münnicha ${ }^{48}$ koncepcja przestrzenna całego zespołu rezydencjonalnego ${ }^{49}$. W czasach Mniszchów przy Senatorskiej wprowadzono rozwiązanie w typie entre cour et jardin. Osiowość założenia została zachwiana przez konieczność dostosowania kompozycji do topografii posesji (il. 15). W konsekwencji ogród podzielono na trzy części, obejmujące czterokwaterowy salon, tarasy oraz wał, z którym było „pięknie w ogrodzie" 50 . W korespondencji z lat 1717-1718 relacjonowano prace przy altanie ${ }^{51}$. O istotnej roli kontekstu przestrzennego jako czynnika warunkujące-

\footnotetext{
48 Jak zostało wspomniane, generał był także odpowiedzialny za projekty oficyn; ZNiO, 2664/I, k. 49, 63-64.

${ }^{49}$ We wspomnianym wcześniej inwentarzu z 1708 r. udokumentowano już istnienie alei lipowej oraz dwóch fontann, w tym usytuowanej w centrum założenia, przedstawiającej ,jedną osobę drugą dźwigającą”; PUTKOWSKA, „Ogród...”, s. 191.

${ }^{50} \mathrm{ZNiO}, 2664 / \mathrm{I}, \mathrm{k} .54$. Na szczególną uwagę zasługuje weduta Canaletta z przedstawieniem pałacu Błękitnego, na której został udokumentowany fragment ogrodu Mniszchów wraz z parkanem.

${ }^{51} \mathrm{ZNiO}, 2664 / \mathrm{I}$, k. 54.
} 
go recepcję pałacu świadczy również figura św. Jana Nepomucena, którą w 1731 r. wykonał Giovanni Lievorati ${ }^{52}$.

\section{Wnętrza palacu}

Informacje o dyspozycji wnętrz można odnaleźć w korespondencji Münnicha i Rybczyńskiego. W liście z 22 kwietnia 1717 r. generał relacjonował budowę i wyznaczanie wysokości pomieszczeń parteru ${ }^{53}$. Ich układ mimo licznych przekształceń pozostaje czytelny w istniejącej bryle ${ }^{54}$. Od strony północnej (ogrodowej) urządzono trzy gabinety: „Wielki”, gabinet Mniszcha (przeznaczony na bibliotekę lub archiwum) i jego małżonki). Podwyższenie sal o kilka stóp i ich nowe rozplanowanie zostały przez inżyniera uzasadnione chęcia zapewnienia większej wygody ${ }^{55}$. Z późniejszych przekazów Rybczyńskiego wyłania się obraz autora projektu jako osoby uwzględniającej kwestie bezpieczeństwa (unikanie drewna w pobliżu kominków, by zniwelować ryzyko pożarów ${ }^{56}$ ), użyteczności (wymiana desek w sali balowej, by nie uginała się w czasie tańca ${ }^{57}$ ) oraz dążącej do estetyki form, nawet jeśli znacznie podnosiło to koszty ${ }^{58}$. Wydaje się oczywiste, że skoro Münnich przywiązywał wielką wage nie tylko do bryły, lecz także do wykończenia detali elewacji (modyfikacje już wykonanych elementów ${ }^{59}$, kamienne oprawy okien ${ }^{60}$ ), to nie zaniedbał też wystroju sal. Wedle projektu generała w pałacu wystawiano schody, „które bardzo dobre będa, żadnej zakrętki nie będzie, na te wschody grube i szerokie bale dębowe obstalować mi [Rybczyńskiemu] kazał i już one mam, sklepienia i mury pod wschody murowali przez ten tydzień mukarze, i co się Imć Generałowi nie podobało kazał inaczej dawać"61.

Stosunkowo duża ilość materiałów ikonograficznych prezentujących dziedziniec z ogrodzeniem i główną fasadę kontrastuje z brakiem przekazów dotyczących wystroju wnętrz ${ }^{62}$.

\footnotetext{
${ }^{52}$ Pomnik udokumentowany na obrazie Canaletta z 1779 r. jest jedynym sygnowanym dziełem artysty; zob. Michał WARDZYŃSKI, „Giovanni Lievorati - the Casus of an Italian Sculptor in Early Eighteenth-Century Warsaw”, [w:] Artyści znad jezior lombardzkich w nowożytnej Europie..., s. 354-355.

${ }^{53} \mathrm{ZNiO}, 2697 / \mathrm{II}$, k. 169-170.

${ }^{54}$ Za możliwość dokładnej analizy wnętrz pałacu pełniącego obecnie funkcję siedziby Ambasady Królestwa Belgii serdecznie dziękuję Pani Ambasador Colette Taquet.

${ }^{55} \mathrm{ZNiO}, 2697 / \mathrm{II}$, k. 169; ZNiO, 2664/I, passim.

${ }^{56} \mathrm{ZNiO}, 2664 / \mathrm{I}, \mathrm{k} .20$.

${ }^{57}$ Pan Generat [...] niektóre belki w wielkiej sali dolnej każe wyrzucić $i$ żeby grubszych dostać $i$ wprawić, a to dla tańców, aby się podłoga nie uginała na tak wielkiej szerokości (ZNiO, 2664/I, k. 76).

${ }^{58}$ Pan Generat Menich wokowat mnie do siebie pokazujac mi model okien, z których dwa, jedno górne, drugie dolne dębowe w kratki stolarz zrobił, jakich tu mody w żadnym pałacu nie nasz. Będa osobliwe, ale będa siła kosztować (ZNiO, 2664/I, k. 31).

${ }^{59}$ W przeszty czwartek Im Pan General Menich wziat mnie z soba do pałacu JWWMM Pana Dobrodzieja, gdzie byli rzemieślnicy z oknami już okowanemi bez szkła przyprawujac one, a to dla uważania proporcyi, kazat ich więcej robić, te zaś gotowe kazat wtożyć do skarbca. Kraty zelazne, które tak rok robiono inaczej przerabiać każe Imć Pan Generat (ZNiO, 2664/I, k. 46).

${ }^{60}$ Kamienie z ogroda wschody, które ja na wschody życzyt obrócić, Im P. General daje do okien na drugim piętrze, azali i na wschody wystarczy i do okien, bo i w oknach pięknie widzę z niemi (ZNiO, 2664/I, k. 20).

${ }^{61} \mathrm{ZNiO}, 2664 / \mathrm{I}, \mathrm{k} .50$.

${ }^{62} \mathrm{Z}$ pałacem przy ul. Senatorskiej (nr hip. 471) błędnie utożsamiono dokument odnoszący się do siedziby Jana Karola Mniszcha przy ul. Miodowej (nr hip. 484) i sporządzony w 1760 r. - post fata właściciela, który zmarł rok wcześniej; zob. Wizya pałacu warszawskiego Jana W. Mniszcha podkomorzego litewskiego, ZNiO, sygn. DE-2566. Tekst został powiązany z obecną siedzibą Ambasady Królestwa Belgii przez Marka Kwiatkowskiego (op. cit., s. 18-19), który nie wskazał wprawdzie źródła informacji o wnętrzach przy ul. Senatorskiej, przywołał jednak bez wątpienia fragmenty powyższego opisu.
} 

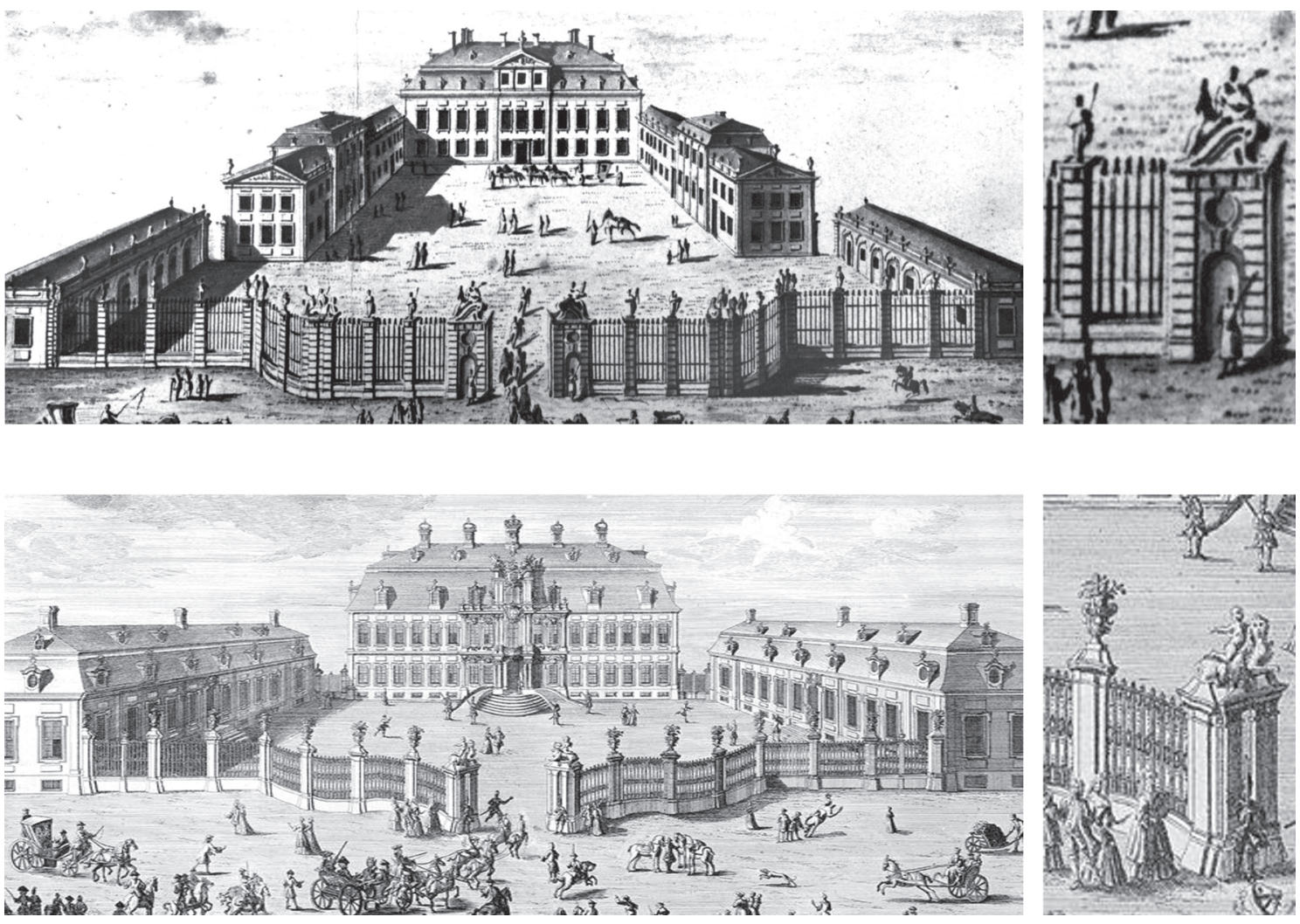

16. Od góry: pałac Mniszchów w Warszawie, fragment Prospect von Warschau Franza Conrada Schmidta, 1740; Johann Rudolph Fäsch, Pałac Jacoba Heinricha von Flemminga (tzw. Holenderski) w Dreźnie, miedzioryt, 1715. Fot. Sächsische Landesbibliothek, Drezno

Z 1727 r. pochodzi list, w którym marszałek wielki koronny pisał do żony w sprawie pożyczenia od „Pani Radogoskiej” do skopiowania wizerunków hetmanów Jabłonowskiego, Sieniawskiego, Potockiego i Lubomirskiego ${ }^{63}$. Wyposażenie pozostałych siedzib Józefa Wandalina Mniszcha może sugerować, jak wyglądały sale w nowo wybudowanym pała$\mathrm{cu}^{64}$. Splendoru wymagała również jego ranga miejsca, w którym organizowano bale, nierzadko z udziałem Augusta II $^{65}$.

\section{Ogrodzenie - rzeźby}

Zależność od architektury Saksonii wykazywało też dekoracyjne ogrodzenie. Jego analizę prezentował Jakub Sito, wskazując na podobieństwo do parkanu wspomnianego wyżej pałacu Holenderskiego w Dreźnie ${ }^{66}$. Na miedziorycie Johanna Rudolpha Fäscha

\footnotetext{
${ }^{63} \mathrm{ZNiO}, 2646 / \mathrm{I}$, s. 108.

${ }^{64}$ Najbardziej reprezentatywnym, powszechnie znanym świadectwem zamożności i ambicji magnata jest inwentarz zamku w Laszkach Murowanych z 1748 r.; Inwentarz zamku laszeckiego (ZNiO, sygn. DE-4955), wydany przez Mieczysława Gębarowicza; zob. Mieczysław GĘBAROWICZ, Materialy źródlowe do dziejów kultury i sztuki XVI-XVIII w., Wrocław 1973, s. 28-93.

${ }^{65}$ Por. Kuryer Polski, 1731, nr. 56, s. 242; BERDECKA, op. cit., s. 10; ŻÓRAWSKA-WITKOWSKA, op. cit., s. 403; BARCZYK, „Ambasada...”, s. 104.

${ }^{66}$ Jakub SITO, Wielkie warsztaty rzeźbiarskie Warszawy doby saskiej. Modele kariery-formacja artystyczna - organizacja produkcji, Warszawa 2013, s. 169.
} 


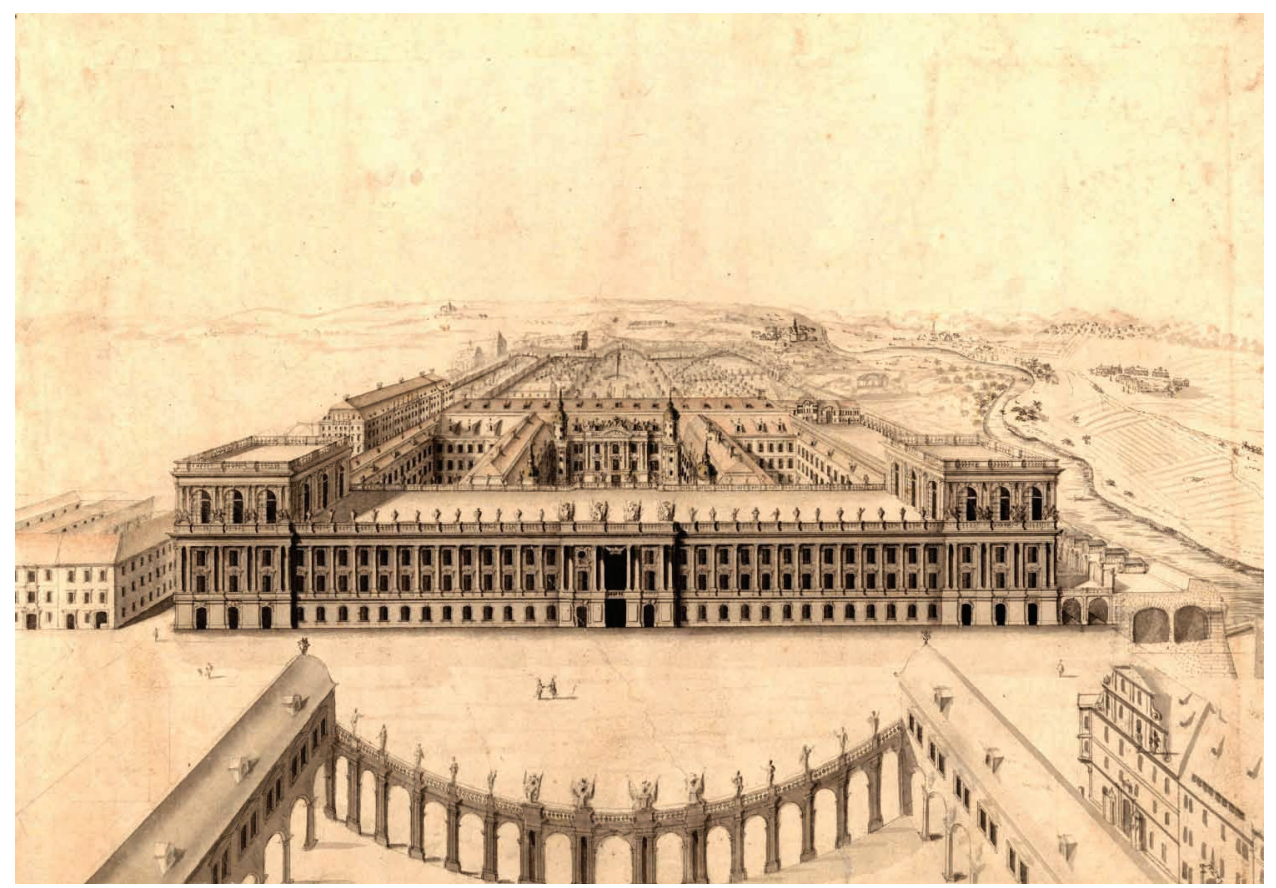

17. Matthäus Daniel Pöppelmann, project zamku rezydencjonalnego w Dreźnie, 1701-1715. Fot. Sächsische Landesbibliothek, Dresden

z 1715 r. paradny dziedziniec poprzedzony jest parkanem o wyłamanej linii, tworzonym przez słupki zwieńczone wazami. Na filarach ujmujących przejazd bramny widnieją sfinksy dosiadane przez putta. W siedzibie Mniszcha, powstałej niewiele później, zastosowano analogiczny, choć nie identyczny układ. Wyłamaną linię parkanu z bramą na osi tworzyły boniowane słupki, na których ustawiono 14 pojedynczych rzeźb oraz 6 grup figuralnych. Wśród personifikacji widocznych na obrazie Canaletta można dostrzec postacie z orłem oraz globusem. Za twórcę posagów uznany został nadworny rzeźbiarz Johann Georg Plersch ${ }^{67}$. Na zasadność atrybucji poza charakterem dzieł wskazuje ranga artysty oraz szacowany czas powstania prac, określany na lata 1733-1737 (il. 16) ${ }^{68}$. Powiązania Plerscha z Mniszchami były również widoczne w kolejnym pokoleniu, gdy po śmierci żony Jerzego Augusta, syna Józefa Wandalina, wykonał nagrobek w warszawskim kościele Reformatów ${ }^{69}$.

Niewątpliwie pałac Holenderski stanowi najbardziej oczywisty wzorzec dla rezydencji Mniszcha. Należy jednak podkreślić, że zbliżony sposób myślenia o elementach architektoniczno-rzeźbiarskich, wprowadzanych w formie bram, ogrodzeń czy portali, można dostrzec w projektach Matthäusa Daniela Pöppelmanna z lat 1701-1715 (il. 17). Półkolisty ciagg arkad wieńczonych rzeźbami figuralnymi, widoczny na projekcie przebudowy zamku drezdeńskiego, tworzy ażurową strukturę, swego rodzaju przegrodę zamykającą pierzeję placu ${ }^{70}$. Cechami łączącymi powyższe projekty z pałacem Mniszcha jest rzeźbiarskie kształtowanie architektury parkanów, których integralną część stanowią pełnoplastyczne

\footnotetext{
${ }^{67}$ Ibid., s. 168-169.

${ }^{68}$ Datę początkową wyznacza brak ogrodzenia na planie Wernecka powstałym w roku 1732 r. i jego uwzględnienie na zdecydowanie późniejszym planie Hübnera. Pytaniem otwartym pozostaje oczywiście dokładność pomiarów - być może parkan został pominięty lub był właśnie wznoszony.

${ }^{69}$ SITO, op. cit., s. 205.

${ }^{70}$ Sächsische Landesbibliothek Dresden. Signatur/Inventar-Nr.: SLUB/HS Mscr. Dresd. L. 4
} 

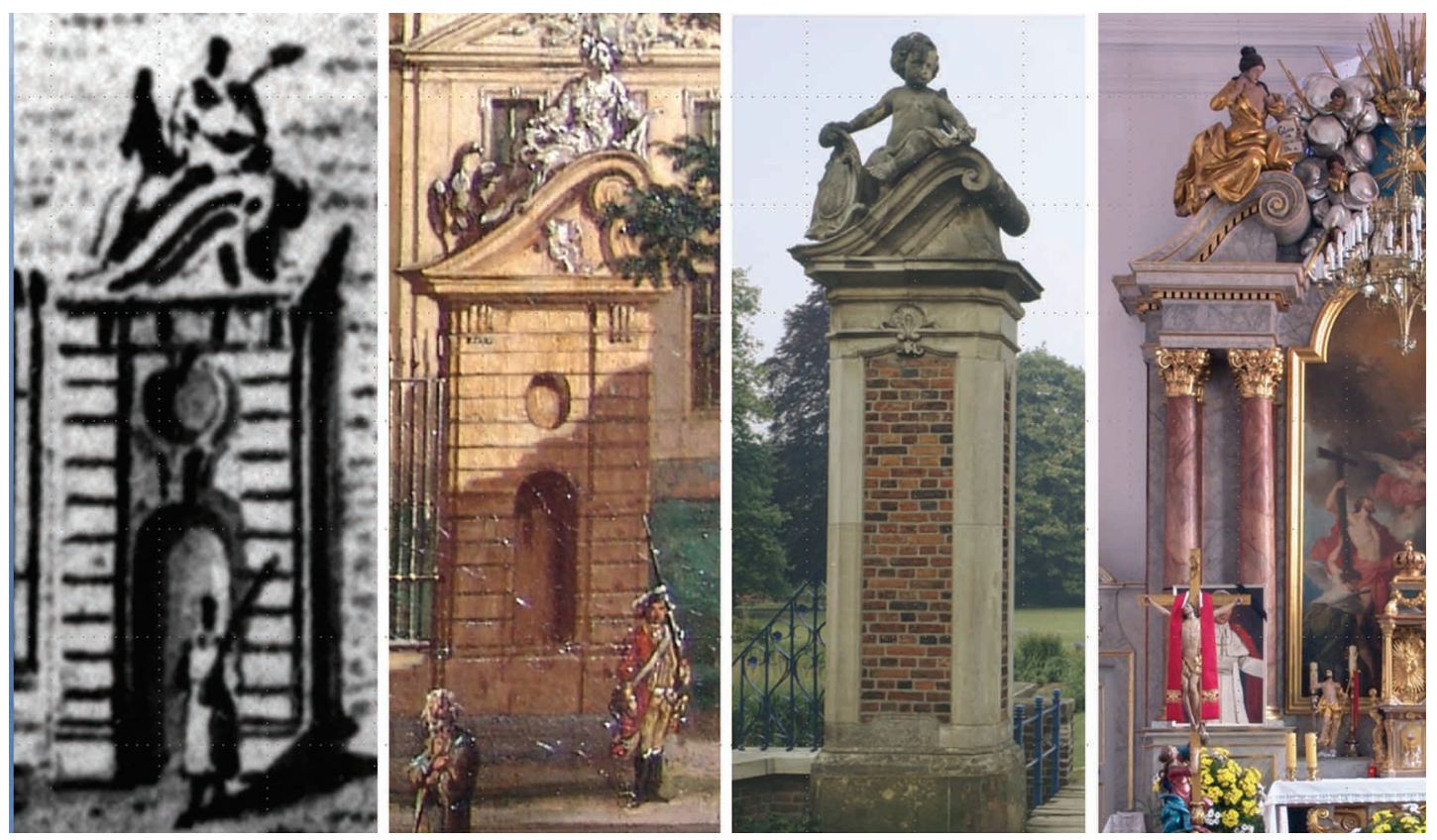

18. Od lewej: brama pałacu Mniszchów w Warszawie, fragment Prospect von Warschau Franza Conrada Schmidta, 1740; fragment obrazu Bernarda Bellotta (zob. il. 5), 1779; Johann Conrad Schlaun, brama parku zamkowego w Lembeck, 1686/1700, modyfikacja po 1729; Carl Friedrich Pöppelmann, ołtarz główny kościoła parafialnego w Piasecznie, 1736. Fot. Jakub Sito, 2009

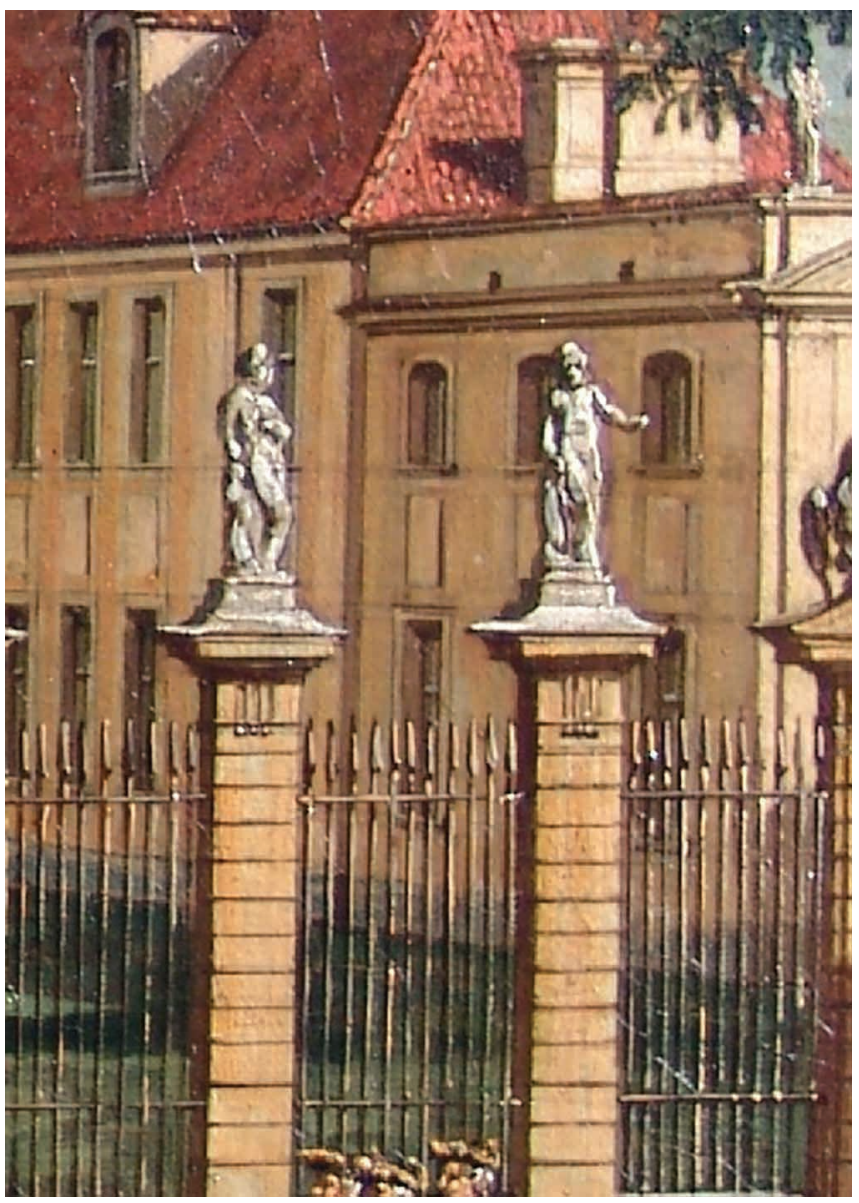

19. Posagi „Persuesza”

$i$,Andromedy" z ogrodzenia pałacu Mniszchów w Warszawie, fragment obrazu Bernarda Bellotta (zob. il. 5), 1779 

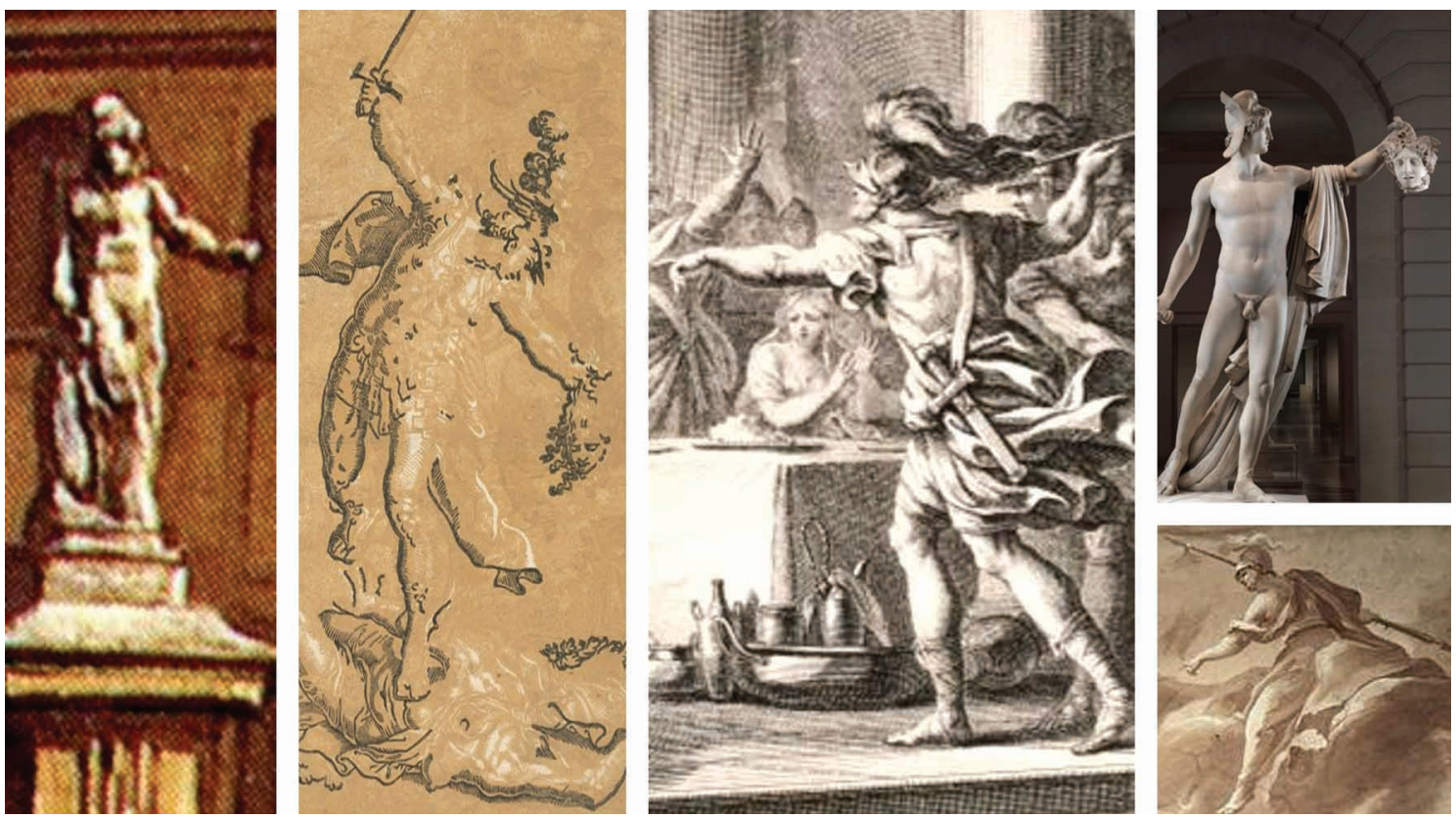

20. Od lewej: „,Perseusz” z ogrodzenia pałacu Mniszchów w Warszawie, fragment obrazu Bernarda Bellotta (zob. il. 5), 1779; krag Marco Pino, Perseusz, Siena, pot. XVI w.

Fot. Metropolitan Museum of Art w Nowym Jorku; Jean-Charles Baquoy, Perseusz, 1721-1777. Fot. Eazienki Królewskie w Warszawie; Antonio Canova, Perseusz, 1804-1806. Fot. domena publiczna; Franz Josef Spiegler, Perseusz, 1724-1725. Fot. Deutsche Fotothek
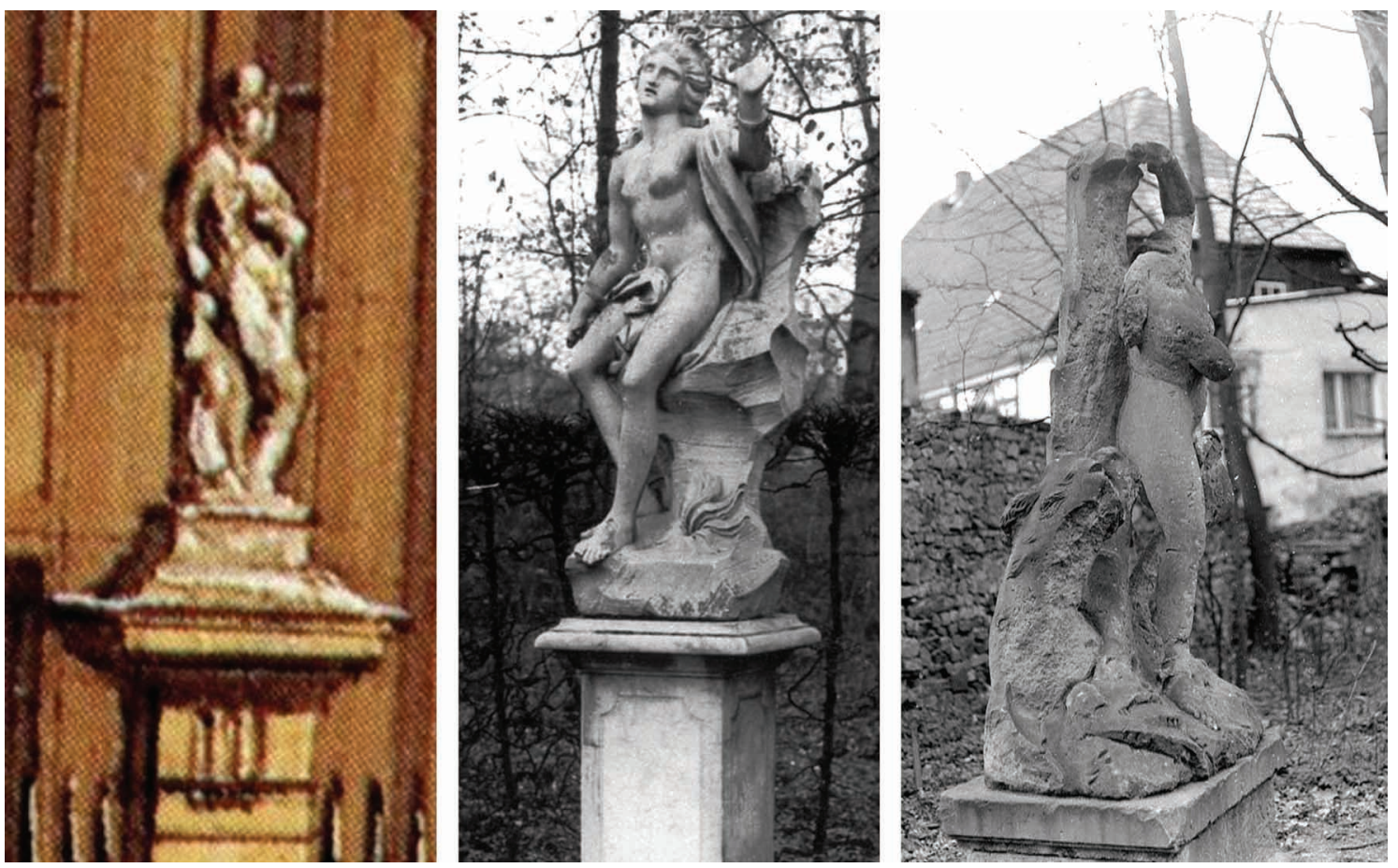

21. Od lewej: „Andromeda” z ogrodzenia pałacu Mniszchów w Warszawie, fragment obrazu Bernarda Bellotta (zob. il. 5), 1779; Andromeda, Sanssouci- Postdam, 1701.

Fot. Sächsische Landesbibliothek, Drezno; Lorenzo Mattielli, Andromeda, 1. pot. XVIII w. Fot. Sächsische Landesbibliothek, Drezno 
figury. Uwagę zwracają też esowato wygięte, spłaszczone przyczółki wieńczące filary bramne i dźwigające pełnoplastyczne personifikacje. Redakcja form znajduje analogie chociażby w zrealizowanym projekcie ołtarza Carla Friedricha Pöppelmanna w Piasecznie $^{71}$, a także w dziełach Johanna Conrada Schlauna, jak brama parkowa w Lambeck (il. 18), gdzie analogicznie uformowano nie tylko same przyczółki, lecz także pozy umieszczonych na nich figur.

Nierozstrzygalne pozostaje pytanie o program ideowy warszawskich rzeźb. Słaba czytelność figur w zachowanych materiałach ikonograficznych pozwala na identyfikację jedynie części atrybutów, takich jak orzeł czy globus, widoczne są również sfinksy. Najbardziej charakterystyczną postacią jest nagi mężczyzna jedynie w nakryciu głowy, wsparty o tarczę i wyciągający przed siebie lewą rękę, widoczny na obrazie Canaletta (il. 19). Zakładając, że dzieło malarza jest odzwierciedleniem rzeczywistego wyglądu warszawskiego pałacu Mniszcha, „niewzbogaconego” przez fantazję artysty ${ }^{72}$, postać tę możemy identyfikować z Perseuszem, którego liczne wizerunki odnajdujemy w nowożytnym malarstwie i rzeźbie, a zarazem kontynuującymi ikonografię wcześniejszych epok. Z licznych przykładów uwidaczniających analogie wystarczy przywołać drzeworyt powstały w kręgu oddziaływania sztuki Marco Pino, sztych wykonany przez Jean-Charles'a Baquoy (1721-1777) oraz fresk Franza J. Spieglera z lat 1724-1725, na którym jednak bohater ubrany jest w długą szatę. Perseusz w hełmie Hadesa, dumnie prezentujący głowę Gorgony, został również przedstawiony w rzeźbie Antonia Canovy (il. 20). Najczęściej stosowanymi atrybutami tego boga były czapka, głowa Meduzy (realna lub sprowadzona do dekoracji tarczy) oraz broń spoczywająca w wyciągniętej dłoni (włócznia lub miecz). Ostatniego z elementów nie można dostrzec na weducie Canaletta, lecz poza postaci wyraźnie sugeruje możliwość umieszczenia tego rodzaju przedmiotu w lewej ręce. Gest może być ponadto uzasadniony przez wprowadzenie „relacji psychicznych” pomiędzy figurami ustawionymi na kolejnych słupkach ogrodzenia. Opisywany bohater zwraca się w kierunku sąsiedniej postaci, umieszczonej po stronie zachodniej. Gdyby hipotetyczna identyfikacja Perseusza mogła być przyjęta, kobiecy posąg najprawdopodobniej przedstawiałby Andromedę. Co więcej, poza postaci jest zbieżna z licznymi wizerunkami etiopskiej królewny. Przywołać można chociażby wcześniejszą o ponad sto lat figurę Michelangela Naccherina ${ }^{73}$, pracę z ogrodu Sanssouci w Postdamie (1749) czy pozostałości rzeźby Lorenza Mattiellego (il. 21) ${ }^{74}$. Za czasów Józefa Wandalina Mniszcha nawiązywano do dziejów Perseusza przede wszystkim przez użycie motywu głowy Meduzy (widnieje ona np. na zbroi Jana III Sobieskiego namalowanej na portrecie ze zbiorów wilanowskich ${ }^{75}$ ). Tarczę $\mathrm{z}$ głową mitologicznej postaci podtrzymuje personifikacja umieszczona na rewersie medalu wybitego z okazji zdobycia Kamieńca Podolskiego w 1699 r.; jego awers zdobi podobizna Augusta II, który zainicjował powstanie pamiątki. Należy zarazem podkreślić, że powyższa propozycja odczytu fragmentu programu ikono-

\footnotetext{
${ }^{71}$ Konsekracja kościoła po modyfikacjach przeprowadzonych z fundacji Aleksandra Józefa Sułkowskiego, obejmujących m.in. wzniesienie głównego retabulum, miała miejsce w 1736 r.; zob. Jakub SITO, „Ołtarz główny kościoła w Piasecznie - fundacja królewskiego faworyta”, [w:] Poza Warszawq. Arcydzieła plastyki dawnej na Mazowszu, red. Michał WARDZYŃSKI, Warszawa 2018, s. 193.

${ }^{72}$ Kwestię wierności/wiarygodności widoków Warszawy Canaletta omawia Małgorzata OMILANOWSKA, „Jak na obrazach Canaletta. Rola wedut Bernarda Bellotta w odbudowie warszawskich zabytków”, [w:] ead., Kreacja, konstrukcja, rekonstrukcja. Studia z architektury XIX-XXI wieku, Warszawa 2016, s. 361-380.

${ }^{73}$ Rzeźba z lat 1616-1618 znajduje się Gallerii Palatina (Palazzo Pitti we Florencji).

${ }^{74}$ Dokumentacja w zbiorach: Sächsische Landesbibliothek - Staats- und Universitätsbibliothek Dresden (d. 81225671).

${ }^{75}$ Obraz (olej na płótnie) datowany jest post 1783; Muzeum Pałacu Króla Jana III w Wilanowie, sygn. Wil. 1348.
} 


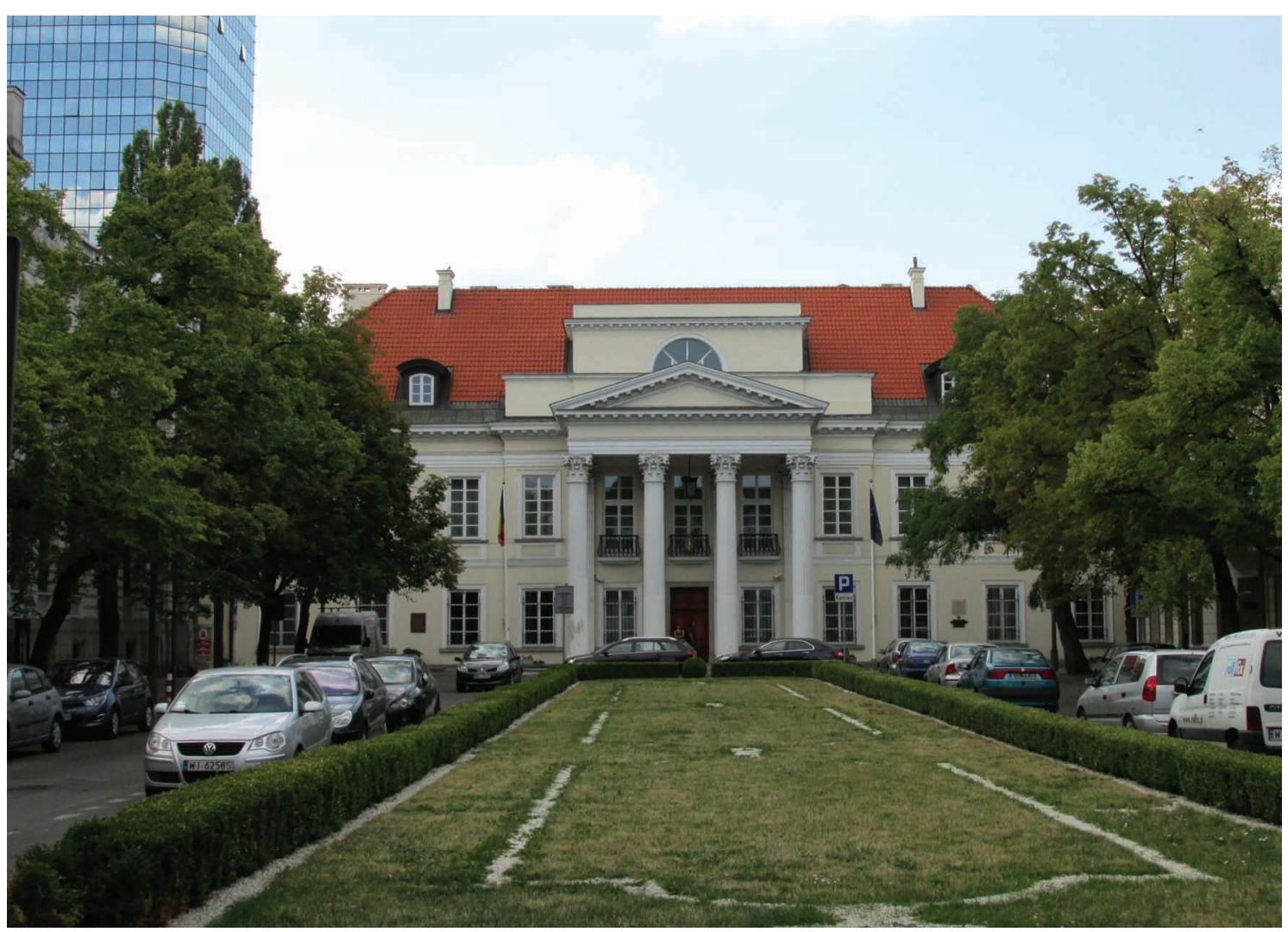

22. Pałac Mniszchów w Warszawie, stan obecny. Fot. Alina Barczyk, 2017

graficznego jest wyłącznie jedną z możliwości, albowiem podobieństwo do hełmu Hadesa wykazuje m.in. nakrycie głowy Tankreda, bohatera Jeruzalem wyzwolonej Torquata Tassa, choć to skojarzenie wydaje się jednak mniej uzasadnione.

$* * *$

Przywołane powyżej zagadnienia tworzą jedynie zarys kilku wybranych wątków, uwidaczniających charakter siedziby przy ul. Senatorskiej (il. 22). Silna pozycja Józefa Wandalina Mniszcha na dworze królewskim stała się jednym z głównych powodów zaznaczenia swej obecności w przestrzeni architektoniczno-urbanistycznej Warszawy. Wcześniej podczas przyjazdów do stolicy wraz z Augustem II miejscem zamieszkania arystokraty był Zamek Królewski ${ }^{76}$. Mimo prestiżu miejsca, zakres obowiązków przynależnych marszałkowi wielkiemu koronnemu tym bardziej skłaniał do stworzenia reprezentacyjnej siedziby, podporządkowanej funkcjom ceremonialnym. Charakter bryły i kompozycji przestrzennej poświadcza rolę Saksonii i wywodzących się z niej budowniczych w rozwoju sztuki Warszawy w okresie panowania Wettynów, zyskującą uzasadnienie w sferze polityki i zainteresowań kulturalnych magnatów. Dzięki nowatorskim rozwiązaniom konstrukcyjnym pałac stał się istotnym przykładem recepcji architektury Drezna na terenie Rzeczypospolitej.

\footnotetext{
${ }^{76}$ Konstancja z Tarłów Mniszchowa, żona marszałka, podczas pobytu w Warszawie, wybierała różne miejsca zakwaterowania. Przykładowo wiosną 1715 r. przeprowadziła się z Zamku Królewskiego na przedmieścia, do pałacu, „gdzie i inne damy stają" - sąsiadującego z dawną siedzibą Teresy z Bielińskich Działyńskiej, zakupioną przez monarchę; zob. A z Warszawy nowiny te.... Listy Jadwigi Rafałowiczówny do Elżbiety Sieniawskiej z lat 1710-1720, red. Bożena POPIOŁEK, Kraków 2000, s. 90.
} 


\section{The Palace 'of the Kind You Have Nowhere Else in Poland'. Saxon Inspirations in the Architecture of the Warsaw Residence Józef Wandalin Mniszech, Grand Marshall of the Crown}

The raising of the residence of Józef Wandalin Mniszech (1670-1747) in Senatorska Street was one of the major constructing projects in Warsaw in the 1720s. The office of the Grand Marshal of the Crown held by Mniszech, the palace's owner, stipulated the necessity to create ceremonial space. The genesis and importance of extremely novel architectural forms of the facility, including e.g. mansard roof, become justifiable once the political impact of the palace's owner and his broad intellectual horizons, the alterations of royal residences undertaken in the period, as well as a wider European context, are taken into account. What emerges as the main reference point is the architecture of Saxony. Interestingly, craftsmen working simultaneously for Augustus II and his projects, were employed to work on the Marshal's residence.

The analysis of the preserved archival records allows to unequivocally affiliate the construction with General Burkhard Christoph von Münnich, who being a hydraulic engineer and architekt militaris served at the court of Augustus II. Let us remind that the Count won fame as the builder of the Peter and Paul Fortress where in 1734 he continued its construction after the death of Domenico Trezzini. Contrary to the generally ascertained view, Münnich did not leave Warsaw for good in 1721. On 25 April and 16 May 1735, he hosted dinners in Warsaw; the latter was held to celebrate the coronation of Empress Anna. The architect may have met with Mniszech in Saxony where the Grand Marshal travelled regularly. The main part of the project had been implemented by 1718 , however the finishing off works still continued in the latter half of the 1720 s. The Mniszech Residence was highly appreciated by the contemporary and ranked among the most sumptuous magnate residences; it was painted in the panoramas by F. C. Hübner and F. C. Schmidt respectively, and following the re-roofing conducted by Józef's son Jerzy August Mniszech, it was immortalized in the famous painting by Canaletto.
Letters from 1717-18 addressed to Mniszech by Sebastian Rybczyński heading the construction works illustrate the complicated process delaying the completion of the project, such as, e.g.: difficulties with obtaining lime due to low water level and shortage of bricks purchased by other Warsaw 'factories'. Assuming the function of the Grand Marshal of the Crown was possible only by the wealthiest magnates: representation expenses were high. One of these was the ample sum to be paid for the palace in Senatorska Street. The Germans employed to do the construction works expected much higher payment than Polish craftsmen; not only did they demand fees higher than those paid by senators for whom residences were at the time raised in Warsaw, but also those paid for royal projects.

The most novel solution applied in the Mniszech Palace in Senatorska Street was the introduction of the mansard roof testifying to Münnich's designing talents and the owner's aspirations. What is worth emphasizing is the awareness of the fact that the structure was precursory. Rybczyński often reported in his letters that a 'foreign fashion' was visible in the facility, while the construction was conducted 'following the Saxon mode'. The roof may have been the first instance of such a structure in Poland's capital, preceding the roofs on the Blue Palace across the street, the Bieliński residence, as well as on the Brühl and Primate's Palaces.

The character of the mass and spatial composition of the residence of Józef Wandalin Mniszech confirm the role Saxony and stonemasons coming from there played in the development of art in Warsaw under the House of Wettin, being justified in the sphere of politics and cultural interests of the magnates. Thanks to novel structural solutions the Palace became an essential example of the reception of Dresden architecture in the Polish-Lithuanian Commonwealth.

Translated by Magdalena Iwińska 